\title{
Structural evolution of Lavinia Planitia, Venus: Implications for the tectonics of the lowland plains
}

\author{
Carlos Fernández ${ }^{\mathrm{a}, *}$, Francisco Anguita ${ }^{\mathrm{b}}$, Javier Ruiz $^{\mathrm{c}}$, Ignacio Romeo ${ }^{\mathrm{d}}$, Álvaro I. Martín-Herrero ${ }^{\mathrm{e}}$, \\ Alberto Rodríguez ${ }^{\mathrm{e}}$, Carlos Pimentel ${ }^{\mathrm{e}}$
}

aepartanento de Geodinónic a Paleontología Universidad de Huelva, 2107 1 Huelva 5pain.

bepartamento de Petrología y Geoquinica, Universidad Complutense de Madrid, 28040 Madrid, Spair.

"Centro de Biología Molecular, CSIC-Universidad Autônoma de Madrid, 28049 Cantoblanco. Madrid, Spain

'Departamento de Geodinámica Universidad Complutense de Madrid, 28040 Madrid, Spain.

e Seminario de Ciencias Planetarias, Universidad Complutense de Madrid, 28040 Madrid, Spain

Keyword:

Venus

\begin{abstract}
A B 5 T R A C T
This work shows the results of a detailed structural analysis of the deformation belts of Lavinia Planitia Ridge belts and graben and groove belts can be observed at the studied area, while wrinkle ridges and large individual grooves predominate in the smooth plains. Transcurrent components of displacement are commonly observed, and transpression and transtension zones are the rule rather than the exception at most of the studied belts. Along-strike azimuth changes of deformation belts are accommodated by internal variations in the predominance of contractional, transcurrent or extensional structures. The material of the surrounding plains embays most of these deformation belts. The kinematic analysis of this complex network of tectonic structures suggests a broadly synchionous activity of contractional, transcurrent and extensional structures. The maximum horizontal shortening axis determined in this work describes a steady, semi-circular pattern centered at Alpha Regio. This deformation contintued, although with subdued activity, after embayment of the deformation belts by the material of the plains. Future study of the tectonic evolution of the lowland plains should take into account the importance of the coeval history of neighboring uplands and lowlands.
\end{abstract}

\section{Introduction}

Almost a $30 \%$ of the Venusian surface is formed by lowlands (Masursky et al., 1980), typically $1-3 \mathrm{~km}$ under the planet mean radius and showing a geoid negative anomaly (typically $-10 \mathrm{~m}$ ). The lowlands" most interesting features are wrinkle ridges and deformation belts. Wrinkle ridges are ubiquitous throughout the inner Solar System (Schultz, 2000). They are interpreted as formed in a mechanically weak layer above blind thrust faults (e.g., Schultz, 2000). In 80\% of the lowlands, wrinkle ridges show a common azimuth. Sandwell et al. (1997) have calculated the shortening caused by the wrinkle ridges in $2-5 \%$

The deformation belts have received an ample attention, but a consensus on their origin has not been reached. One of the main unsolved questions on the lowlands" tectonics is whether the belts and wrinkle ridges represent the dual response of a two-layer unit to a single stress field. It is to be remarked that notwithstanding Venus' high surface temperature $(\sim 723 \mathrm{~K})$, its rocks are highly resistant to failure because of their dryness. It is on this basis that most authors agree with Mackwell et al. (1998), who proposed that the absence of water would prevent the existence of a significant mechanical contrast between the lower crust and the upper mantle. Mackwell et al. (1998) recognized however that fast strain rates and thinner crust would favor an upper mantle stronger than the lower crust. Also, the planet could have experienced humid climate epochs (Bullock and Grinspoon, 1996, 2001), during which the presence of water would soften the lithosphere.

Three explanations have up to now been put forward for the deformation belts. Zuber (1987), Bindschadler et al. (1992), and Squyres et al. (1992) hypothesized that the excess density implied from the geoid anomaly would cause compression through the drag of vertical traction. The consequence would be a tendency of the plains to downwelling, which would constitute the return flow of the upwelling characteristic of the volcanic rises. At about the same time, Frank and Head (1990) proposed an evolutionary sequence from wrinkle ridges to deformation belts, in which they supported the hypothesis of a single stress field. Conrad and Hager (2001) advanced a variant of the downwelling idea with their sluggish-lid suggestion, whereby a mantle dragged the lithosphere to which it was mechanically coupled. 
The second altemative was proposed by Bilotti and Suppe (1999), who mapped thousands of wrinkle ridges and, following the suggestion of Sandwell et al. (1997), concluded that these accidents form a global feature caused by the geoid swell-push. This stress, analogous to the terrestrial ridge-push, would produce rifting at the highlands and compression at the lowlands. At the majority of plains (but with important exceptions), wrinkle ridges are paralleJ to the geoid equipotential lines. This geometry would mean that wrinkle ridges were caused by the lateral push of the geoid lighs over the lows. The exceptions were accounted by Bilotti and Suppe (1999) as representing old wrinkle ridge sets, formed when the geoid had a different geometry.

The last of the hypotheses on the lowlands' tectonics is the one by Young and Hansen (2005), who propose delamination as a mechanism, while at the same time discussing whether the ridge belts could be kipukas, or alternatively areas which would concentrate the deformation They disagree with the Frank and Head (1990) sequence, on the basis that wrinkle ridges express a pervasive deformation, while the deformation in the belts is focused. An evaluation of these genetic hypotheses will be carried out in Section 4.

Why is it important to re-evaluate the jdeas proposed on the Venusian ridged plains tectonics? The origin of lithos pheric deformations on a stagnant lid planet stands out as one of the main questions in the geology of the Solar System. Venus shows strong luints of a convective mantle (e.g., Anderson and Smrekar, 2006). but the link between these putative movements and the genesis of geologic structures has not been easy to trace. This planet shows thus a tectonic evolution distinct from Earth with its moving plates, and Mars where rocks are tectonic fossils. Moreover, while a part of the record of the relatively old (or, rather, less young) Venus is kept at the tesserae terrains, tectonics is best displayed in the ubiquitous radar dark plains, where the structural geology analyses can be carried out with outmost proficiency. The plains are thus a useful key to unravel the history of Venus. And of all the ridged plains, and along with Vinmara Planitia, Lavinia Planitia exhibits the maximum concentration of deformation belts and stands out therefore as the best instance to tackle the problem of the Venusian tectonics.

\section{The geology of Lavinia Planitia}

Laviria Planitia (Fig. 1), a roughly triangle-sluaped depression $2000 \mathrm{~km}$ across and centered at $45^{\circ} \mathrm{S}, 345^{\circ} \mathrm{E}$, is bounded by two deformation belts, Morrigan Linea to the west and Kalaipahoa Linea to the south; and by one tessera terrain, Lhamo and Tyche Tesserae, and a long deformation belt to the east. Parts of Lavinia Planitia are covered by three massive lava outflows: Mylitta Fluctus, erupted from the south, Kaiwan Fluctus from the east, and Eriu Fluctus from the northeast.

Lavinia Planitia is the best studied of the ridged plains. Squyres et al. (1992) published its first detailed description, and Magee and Head (1995) also wrote a monographic paper on it. Koenig and Aydin (1997, 1998) described some outstanding tectonic elements, and Ivanow and Head $(2001,2007)$ made its geologic map. The deformation belts ase linear zones of concentraced deformation hundreds of kilometers long and tens of kilometers wide, and with a typical spacing of $200 \mathrm{~km}$. Though Magee and Head (1995) describe them as radial, their geometry, as shown by the present work, is more complex. Two main types of deformation belts appear in Lavinia Planitia: ridge belts and fracture or groove belts (Squry res et al., 1992). The intervening plains are pervaded by wrinkle ridges spaced $10-20 \mathrm{~km}$.

The belts include large folds, thrusted anticlines, grabens, and strike-slip fractures. The megashears can reach horizontal displacements of tens of kilometers (Koenig and Aydin, 1998).

\section{Structural description of the main deformation belts}

This work is based on a detailed structural study of Lavinia Planitia. In this semse, we agree with Hansen (2000) that "secondary structures absolutely cannot constitute a part of material tuit(s) descriptor or characteristics". This work describes the geometry of and age relationslips between structures. Embayment of structures by younger stratigraphic units (commonly lava flows) is also recorded. Therefore, for the purposes of this work, only two material units are distinguished: (1) pre- and syntectonic units and (2) post-tectonic units, essentially the massive lava outflows cited above (pl unit of Ivanov et al., 2000), that are the only rock units not affected by tectonic structures. Crosscutting relations between structures are sufficient to provide a relative age constraint, consistent across Lavinia Planitia.

Our description of tectonic structures will largely follow the nomenclature proposed by Squyres et al. (1992) in their seminal work about the deformation belts of Lavinia. Ridges are one of the main components of the deformation belts. Individual ridges are convex-upwards, elongate features, of several $\mathrm{km}$ in width and tens of $\mathrm{km}$ in Jength. Commonly, ridges do not appear isolated, but organized in trains or bundles called ridge belts. Ridges are mostly interpreted as contractional structures (e.g., Squyres et al., 1992). Wrinkle ridges are also contractional features, alchough they are less than $1 \mathrm{~km}$ wide Venusian wrinkle ridges are identical to those observed at other planets like Mars or Mercury (e.g., Mueller and Golombek, 2004). Fracture belts are considered as due to extensional tectonics (Squyres et al., 1992) and are formed by complex systems of spatially heterogeneous, anastomosed fractures, commonly paired to define grabens. Long (sometimes exceeding $500 \mathrm{~km}$ ), isolated grabens that appear crosscutting the large plains of Lavinia Planitia were called grooves by Squyres et al. (1992). Besides these classical types of tectonic features, recent studies have shown the presence of transcurrent structures inside and outside Lavinia Planitia (Koenig and Aydin, 1998; Romeo et al., 2005).

The structural analysis has been achieved in six areas (A-F) where detailed structural maps have been constructed. The locations of these areas are shown in Fig. 1. Measurement of the azimuth of the analyzed structures has followed a systematic procedure, with the use of a square grid covering each deformation belt Azimuths have been measured regularly at each grid node, with indication of the type of observed structure: contractional (large ridges), extensional (grabens, extensional fractures, grooves) or transcurrent (structures with features similar to those described by Koenig and Aydin (1998)). Finally, the results are represented in rose diagrams.

\subsection{Area A}

Three types of tectonic features can be observed in this area (Fig. 2), large ridges, wrinkle ridges and extensional fracture belts and grooves. Ridges are wide $(5-10 \mathrm{~km})$ and fairly long (40$60 \mathrm{~km}$. Fig. $2 A$ and $B$ ). Interlimb fold angles representative for these ridges can be approximated considering that the total relief resulting from the folds is less than or equal to the plateau relief at the location of the folds (Ghent and Hansen, 1999). In area $A$ this relief is lower than $0.2 \mathrm{~km}$ (Fig. 2A) corresponding to a fold amplitude of $0.1 \mathrm{~km}$. Accordingly, wavelengths of around $5-10 \mathrm{~km}$ yield average interlimb angles ranging from $175^{\circ}$ to $177^{\circ}$, similar to those found by Ghent and Hansen (1999) in Ovda Regio. Using Eq. (2) of Ghent and Hansen (1999) very modest ( $<0.1 \%$ ) values of shortening are obtained for the ridge belts of area A. They show sigmoid (S-type) geometries and appear associated as right-stepped structures. The bimodal rose diagram of ridges (Fig. 2C) illustrates this curved, Stype geometry, with the circular mean (N25 ${ }^{\circ} \mathrm{E}$; Table 1) coinciding 


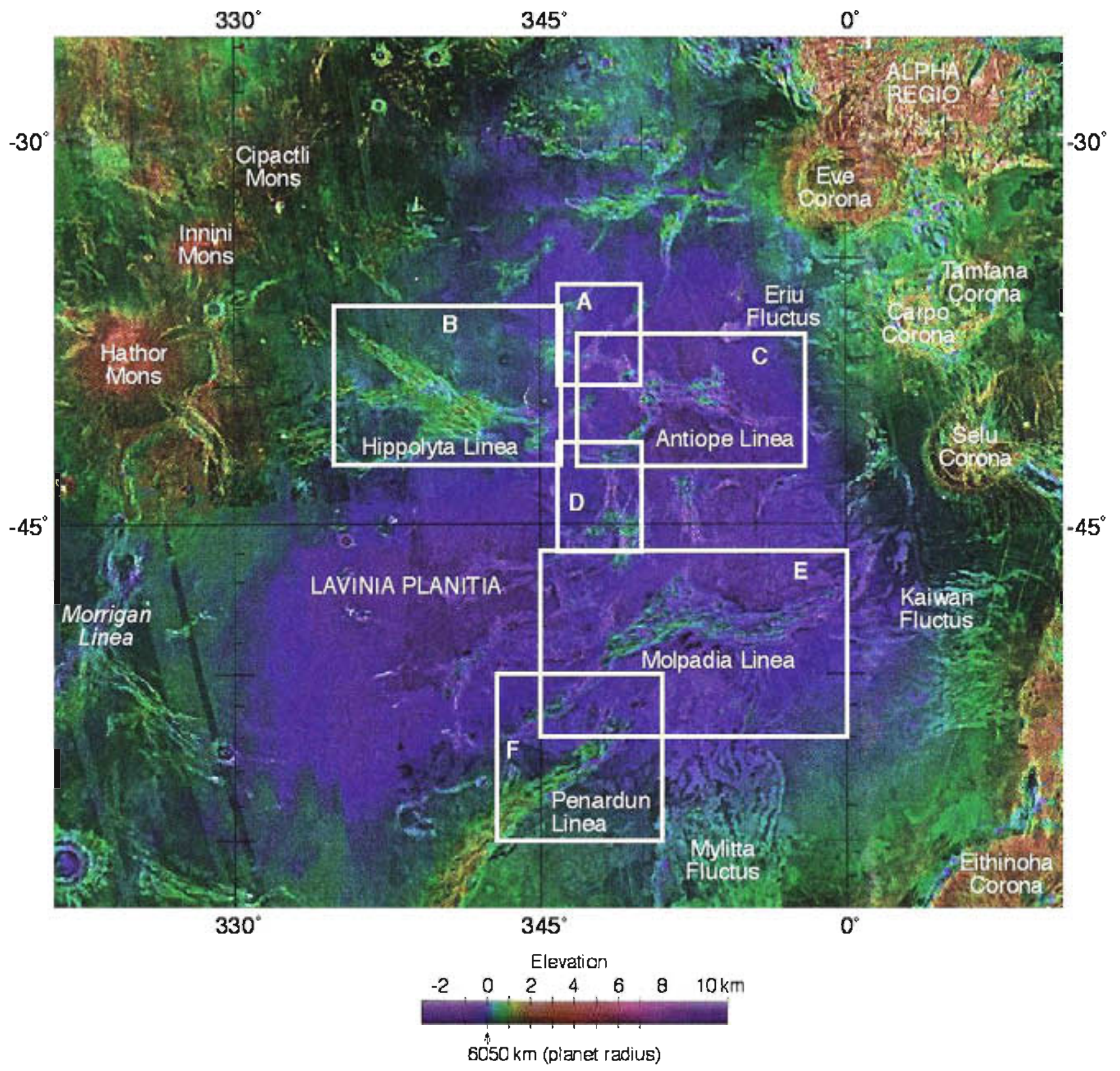

Fig. 1. Topographic map of Lavinia Planita with location of the areas studied in detail in this work (areas A-F). Mercator projection.

with one of the modes (the long, central segment of the sigmoids). whereas the other mode is deflected clockwise (the tip segments of the sigmoids). At least three ridge belts appear in area A. Ridge belts are elongate, with lengths exceeding $200 \mathrm{~km}$ and more than $50 \mathrm{~km}$ across. The central and northeastern ridge belts are also right-stepped as a whole. Although locally some lava flows can be observed affected by the ridges, most of ridge and groove belts of Lavinia Planitia can be observed embayed by the material of the plains, which is also observed in this area. Azimuth of wrinkle ridges has not been systematically measured nor represented in rose diagrams. However, wrinkle ridges are mostly $\mathrm{N}-\mathrm{S}$ oriented in this area and they show an average spacing of around 10$15 \mathrm{~km}$. However, the strike of the wrinkle ridges changes in the vicinity of the ridge belts, trending sub-parallel to the long axes of the belts. Also the spacing of the wrinkle ridges decreases near the ridge belts, and they show sigmoid geometries and rightstepped patterns (see enlarged area in Fig. 2A). In some cases, wrinkle ridges are observed in prolongation of large ridges that progressively close towards the plains, a feature already described by Squyres et al. (1992). Extensional fractures appear crosscutting most of the ridges and ridge belts, although most of them are embayed by the material of the plains. Individual grooves can extend for more than $100 \mathrm{~km}$ in the center of this image. At the southern half of area $A$, the extensional fractures (mostly grabens) are grouped into several fracture belts striking E-W to NW-SE. The oblique arrangement of grabens with respect to the boundary of some fracture belts (dashed blue lines ${ }^{1}$ in Fig. 2B) is indicative of oblique extension. Both right-stepping and left-stepping grabens can be observed. This topic will be considered in some detail in Section 4. The rose diagram (Fig. 2D) shows a well-defined NW-SEtrending mean direction ( $\mathrm{N} 127^{\circ} \mathrm{E}$, Table 1 ), with only a small scatter around it. Although extensional structures often cross-cut ridges, age relationships between both types of structures are by no means

\footnotetext{
${ }^{1}$ For interpretation of color in Figs. $2-6,8,11,13$ and 14 , the reader is referred to the web version of this article.
} 

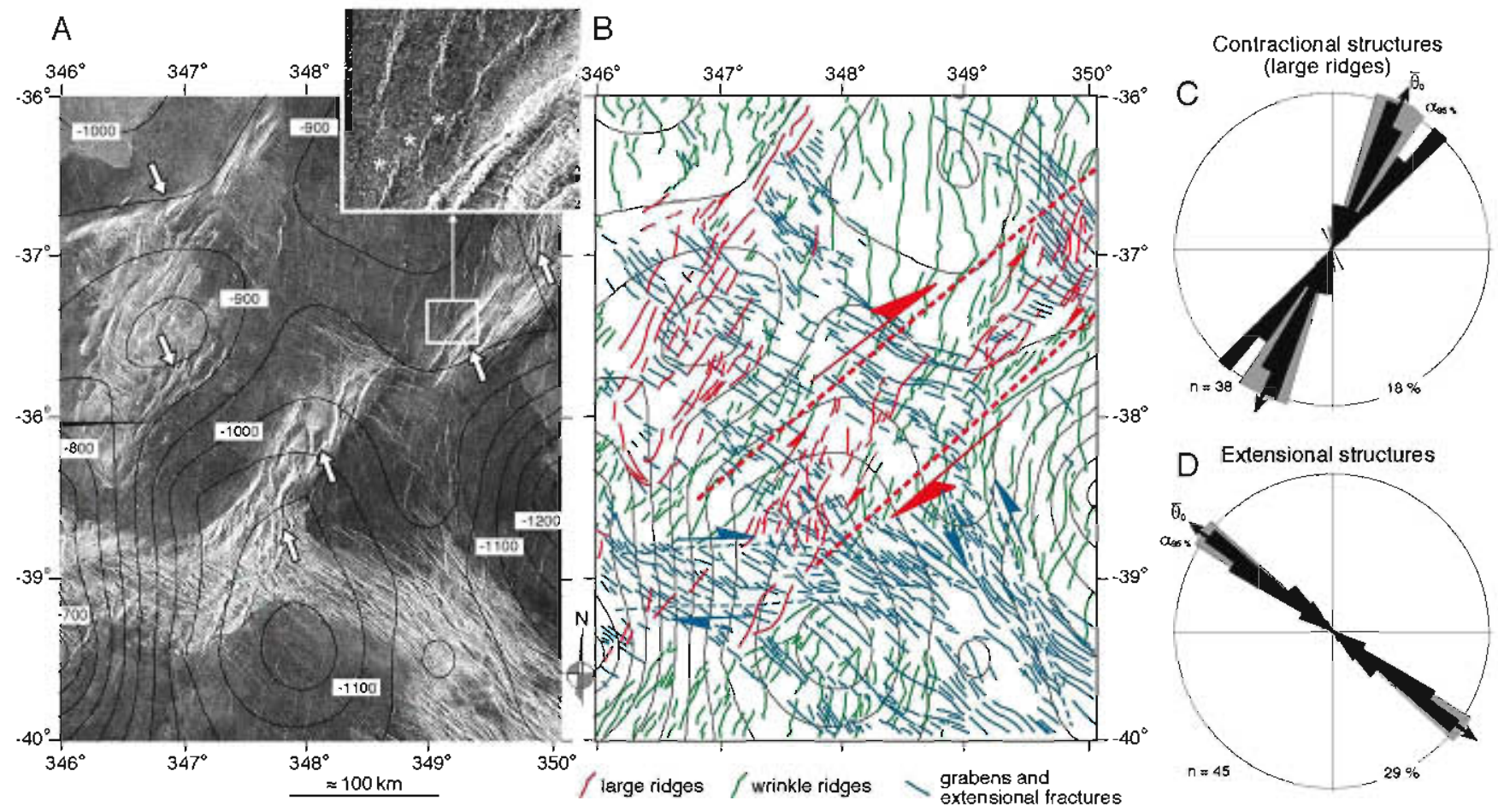

Fig. 2. Structural analysis of area A (unnamed). (A) Magellan Synthetic Aperture Radar (SAR) left-look FMAP image (resolution 1408.13 px/deg) with topographic contours (elevation with respect to the planet radius, $6050 \mathrm{~km}$ ). Contour interval of $50 \mathrm{~m}$. Mercator projection. The enlarged area shows a right-stepped pattern of sigmoid wrinkle ridges near a ridge bett. White arrows point to some examples of right-s tepped individual ridges at the distinct ridge belts of this area. (B) Structural map with interpretation of the horizontal displacement sense for transpressional (red) and transtensional (blue) structures. ( $C$ and $D$ ) Rose diagrams for contractional and extensional structures, respectively. $\theta_{0}$ is the mean circular direction (marked with double-headed arrows) and $\alpha_{95 \%}$ is the $95 \%$ confidence interval around the mean direction. The percentage represented by the outer circle is indicated, and $n$ is the number of measured features. Bin size is of $5^{\circ}$.

obvious (see Section 4). Both sets of structures are generally orthogonal, although oblique arrangements are observed locally (Fig. 2B), a fact which is most apparent when their respective rose diagrams are compared (Fig. 2C and D). Clear transcurrent structures have not

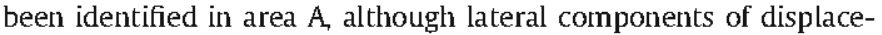
ment can be suggested for most ridge and fracture belts of Lavinia Planitia, as indicated in Section 4.

\subsection{Area B (Hippolyta Linea)}

Hippolyta Linea is one of the main deformation belts of Lavinia Planitia. It is an elongate, NW-SE-striking feature. Hippolyta has also a clear topographic expression (Fig. 3A), as it defines a long ( $\sim 1000 \mathrm{~km}$ ) range standing up to $700 \mathrm{~m}$ above the surrounding plains.

Large ridges in Hippolyta Linea are crosscut by the extensional fractures. The plains low radar backscatter material can be observed to embay the ridge belts and most of the extensional structures. The main feature of ridges at Hippolyta is the trend variation shown by their axial traces (Fig. 3B andC). Three main modes can be observed at the rose diagrams of ridge orientations: NE-SW, NW-SE and WNW-ESE (this late mode is defined by a discontinuous band of ridges located at latitude $-40^{\circ}$ to $-41^{\circ}$ ). The structural map (arrows in Fig. 3B) shows that transition along-strike among these trends is smooth and curved. Lowland materials cover some ridge belts, although the outcropping pattern in non-embayed areas shows sigmoid-like bends enclosing less-deformed, ridgefree, lozenge-shaped areas (Fig. 3B). Commonly, these areas (for instance, the region where the two cross-sections at Fig. 3B meet) coincide with prominent topographic highs. Wrinkle ridges affect only the low-lying plains (Fig. $3 \mathrm{~A}$ and $\mathrm{B}$ ), with an average spacing of $25-30 \mathrm{~km}$ and maximum observed lengths of $100 \mathrm{~km}$. They show a consistent NE-SW trend, sub-parallel to one of the orientation maxima of the large ridges. However, contrasting with area $\mathrm{A}$, wrinkle ridges of Hippolyta Linea do not show along-strike deflections to become sub-parallel to the trend of ridge belts in their vicinity. Instead, they are consistently normal to the extensional fractures.

The grabens of Hippolyta Linea define a rift system characterized by anastomosed geometries (Fig. 3B). lnside the rift, individual grabens show two main directions, $\mathrm{N} 110-115^{\circ} \mathrm{E}$ and $\mathrm{N} 125-130^{\circ} \mathrm{E}$ (Fig. 3D) yielding low-deformation, elongate or lozenge-shaped areas. Lengths of the long axes of these low-deformation areas range from less than $10 \mathrm{~km}$ to around $200 \mathrm{~km}$. The average trend of grabens ( $\mathrm{N} 120^{\circ} \mathrm{E}$, Table 1 and Fig. 3D) is parallel to the axis of the rift. Locally, the grabens show en échelon, curved patterns, mostly with right-stepped geometries, although left-stepping has also been observed. The axis of the long-wavelength topography of Hippolyta Linea coincides with the trend of this rift, although local saddle-type topographic irregularities are mostly associated with the ridge belts, as indicated above. Individual grooves, with lengths of up to $200 \mathrm{~km}$, are observed affecting the subdued plains and show trends sub-parallel to those of the grabens in the large rifts.

En échelon bands of sigmoid grabens are often bounded by WNW-ESE-trending, straight fractures (orange lineaments in Fig. 3B). The average orientation of these structures is $N 107^{\circ} \mathrm{E}$ ( Table 1, Fig. 3E). Their orientation, geometrical association with extensional structures and straight traces enable us to suggest that they are predominantly transcurrent structures, or oblique faults trending parallel to the strike-slip component at a zone of oblique rifting. The term transcurrent fault was used by Sylvester (1988) to describe strike-slip faults confined within the lithosphere, that is, those that are not transforms. In this work, we have preferred to 
Table 1

Statistical measures of the angular orientation data of the different structures observed at the studied zones of Lavinia Planitia.

\begin{tabular}{|c|c|c|c|c|c|c|c|}
\hline \multirow[t]{2}{*}{ Zone } & \multirow[t]{2}{*}{ Structure } & \multirow[t]{2}{*}{$n$} & \multicolumn{3}{|c|}{ Resultant vector } & \multicolumn{2}{|c|}{$\begin{array}{l}\text { Drientation } \\
\text { tensor }\end{array}$} \\
\hline & & & $\theta_{0}$ & $R$ & $\alpha, 95$ & $\vec{t}_{1}$ & $\tau_{1}$ \\
\hline \multirow[t]{2}{*}{ A } & c & 38 & $25^{\circ}$ & 0.87 & $9^{\circ}$ & & \\
\hline & $\mathrm{e}$ & 45 & $127^{\circ}$ & 0.95 & $5^{\circ}$ & & \\
\hline \multirow[t]{2}{*}{ B (Hippolyta Linea) } & $\mathrm{e}$ & 480 & $120^{\circ}$ & 0.97 & $1^{\circ}$ & & \\
\hline & t & 35 & $107^{\circ}$ & 0.96 & $5^{\circ}$ & & \\
\hline \multirow[t]{3}{*}{ C (Antiope Linea) } & $c$ & 44 & $29^{\circ}$ & 0.89 & $10^{\circ}$ & & \\
\hline & $\mathrm{e}$ & 524 & $128^{\circ}$ & 0.97 & $1^{\circ}$ & & \\
\hline & $t$ & 606 & $117^{\circ}$ & 0.96 & $1^{\circ}$ & & \\
\hline \multirow[t]{2}{*}{ D } & $c$ & 43 & $9^{\circ}$ & 0.88 & $8^{\circ}$ & & \\
\hline & e & 49 & $121^{\circ}$ & 0.85 & $9^{\circ}$ & & \\
\hline \multirow[t]{3}{*}{ E (Molpadia Linea) } & $c$ & 314 & $51^{\circ}$ & 0.90 & $3^{\circ}$ & & \\
\hline & e & 175 & $136^{\circ}$ & 0.85 & $5^{\circ}$ & & \\
\hline & $t$ & 977 & $83^{\circ}$ & 0.91 & $1^{\circ}$ & & \\
\hline \multirow[t]{3}{*}{ E (Molpadia North) } & $c$ & 42 & & & & $14^{\circ}$ & 0.81 \\
\hline & e & 143 & & & & $146^{\circ}$ & 0.84 \\
\hline & t & 66 & & & & $93^{\circ}$ & 0.88 \\
\hline \multirow[t]{2}{*}{ E (Molpadia NE) } & c & 109 & $53^{\circ}$ & 0.98 & $2^{\circ}$ & & \\
\hline & $\mathrm{e}$ & 123 & $84^{\circ}$ & 0.92 & $4^{\circ}$ & & \\
\hline \multirow[t]{3}{*}{ E (Molpadia Center) } & $c$ & 44 & $53^{\circ}$ & 0.90 & $7^{\circ}$ & & \\
\hline & $\mathrm{e}$ & 11 & $131^{\circ}$ & 0.97 & $9^{\circ}$ & & \\
\hline & t & 499 & $94^{\circ}$ & 0.96 & $1^{\circ}$ & & \\
\hline \multirow[t]{3}{*}{ E (Molpadia SW) } & $c$ & 119 & $51^{\circ}$ & 0.95 & $3^{\circ}$ & & \\
\hline & $\mathrm{e}$ & 21 & & & & $125^{\circ}$ & 0.72 \\
\hline & $t$ & 289 & $61^{\circ}$ & 0.92 & $2^{\circ}$ & & \\
\hline \multirow[t]{3}{*}{ F (Penardun Linea) } & $c$ & 255 & $33^{\circ}$ & 0.81 & $4^{\circ}$ & & \\
\hline & $\mathrm{e}$ & 120 & $98^{\circ}$ & 0.91 & $4^{\circ}$ & & \\
\hline & $t$ & 108 & $77^{\circ}$ & 0.87 & $5^{\circ}$ & & \\
\hline Fig. $10 \mathrm{~B}$ & $\mathrm{e}$ & 336 & $125^{\circ}$ & 0.99 & $1^{\circ}$ & & \\
\hline Fig. 10D & $\mathrm{e}$ & 258 & $119^{\circ}$ & 0.98 & $1^{\circ}$ & & \\
\hline Fig. 10F & $\mathrm{e}$ & 60 & $122^{\circ}$ & 0.99 & $2^{\circ}$ & & \\
\hline Fig. $10 \mathrm{H}$ & $\mathrm{e}$ & 158 & $120^{\circ}$ & 0.98 & $2^{\circ}$ & & \\
\hline Fig. 10 & $\mathrm{e}$ & 189 & $120^{\circ}$ & 0.94 & $2^{\circ}$ & & \\
\hline
\end{tabular}

Zones A-F refer to the areas outlined in Fig. 1. The measured structures are interpreted as contractional ( $c$, this group includes mainly ridges), extensional ( $e$, it includes grooves and grabens) and transcurrent (t, mainly strike-slip features characterized according to the criteria stated in the main text); $n$ is the number of measured data. Angles are given from North in the clockwise direction. $\theta_{0}$ is the mean direction; $R$ is the mean resultant length, a statistic describing the concentration of data about the mean direction; $\alpha_{95}$ is the Von Mises distribution confidence interval for the mean direction at a significance level of $95 \% ; \vec{t}_{1}$ is the first eigenvector of the orientation tensor measuring the moment of inertia of the distribution, i.e the line oriented so as to be sinultaneously as close as possible to all of the sample lines; $\vec{t}_{1}$ is the greatest normalized eigenvalue of the orientation. tensor. Details of the meaning of the resultant vector and the orientation tensor statistics applied to this type of circular, axial data can be obtained in Mardin (1972). In some samples the statistical description is based on the orientation tensor according to their specific distribution patterns.

open the meaning of this term to include individual structures or, more commonly, sets of structures that show a component of horizontal (strike-slip) displacement. Straight traces and association with stepped and/or sigmoid extensional fractures (like those in Hippolyta Linea described above) are some of the characteristic features of these structures, a topic that will be mentioned in some detail in Section 4.

\section{Area C (Antiope Linea)}

The large-scale structure of Antiope Linea (Fig. 4A and B) bears many resemblances with that of Hippolyta Linea. Ridge belts with sinuous contours define an irregular lattice that is embayed by younger plain materials (Eriu Fluctus) at the eastern half of the studied area. However, more progressive transition from ridged highs to non-ridged lowlands is observed at the western half of Antiope, particularly at its northwestern part (junction with area A). Curvature of ridge swarms (e.g. arrow in Fig. $4 \mathrm{~B}$ ) is also less pronounced in Molpadia than in Hippolyta, as shown in Fig. $4 \mathrm{~B}$ and $\mathrm{C}$. The average strike of individual ridges is $N 29^{\circ} \mathrm{E}$, although with a large scatter (Table $1,95 \%$ confidence interval of $10^{\circ}$ ). Wrinkle ridges are mostly NNE-SSW-oriented, and they define a pattern similar to that described for area $A$, with pronounced changes in orientation towards parallelism with ridge belts and progressive along-strike transitions from large ridges to wrinkle ridges. The wrinkle ridges near Antiope Linea are not always normal to extensional structures (see, for instance, the eastern part of the mapped area, Fig. $4 \mathrm{~B}$ ).

The extensional fractures (mostly grabens) are NW-SE-oriented (Fig. 4D). Average trend is $\mathrm{N} 128^{\circ} \mathrm{E}$ (Table 1 ), and only minor curvatures are observed in some bands with en échelon arrangements bounded by fractures similar to those characterized as transcurrent faults in Hippolyta. The circular mean of transcurrent structures is WNW-ESE (N117 $\mathrm{E}$, Fig. $4 \mathrm{E}$, Table 1 ). The grabens define a rift system at the central part of the mapped area (Fig. 4B) and another rifting structure at the southwestern corner of the map. Rift axes are NW-SE-oriented, and the grabens show internal anastomosed geometries, embracing elongate or lozenge-shaped less deformed areas. These areas are smaller $(<100 \mathrm{~km}$ ) than those of Hippolyta Linea, and are commonly bounded at their longer sides by transcurrent structures. Grooves with lengths of $30-50 \mathrm{~km}$, parallel to the rifts, appear affecting the plains materials to the north of Antiope Extensional structures and wrinkle ridges are covered by young flows, particularly at the eastern part of Antiope (Eriu Fluctus). The topography of Antiope Linea shows a NW-SE-oriented positive relief, although some local highs appear associated with the presence of contractional or transcurrent structures (Fig. 4B).

\subsection{Area D}

This area is located to the southwest of Antiope Linea, and thus, as could be expected, their ridge belts show similar features. Nevertheless, some clear sigmoid, en échelon patterns can be observed at the southern half of area D (Fig. $5 \mathrm{~A}$ and $\mathrm{B}$ ). This generates a scatter in the trends of individual ridges that concentrate around the $\mathrm{Ng}^{\circ} \mathrm{E}$ direction (Fig. 5C, Table 1). Long (>100 km), sub-parallel ridges can be observed at the central part of area $\mathrm{D}$. Average spacing of wrinkle ridges is of $15-20 \mathrm{~km}$ and they show spatial patterns very similar to those of large ridges, often representing their prolongation across the smooth plains (east central border of Fig. 5B). Compared with the precedent areas, extensional fractures are more scattered ( $95 \%$ confidence interval of $9^{\circ}$ ) around the $\mathrm{N} 121^{\circ} \mathrm{E}$ mean direction (Fig. 5D, Table 1). The grabens crosscut the ridges at variable angles (Fig. $5 \mathrm{~B}$ ) and tend to become arranged in en échelon patterns that define E-W- and NNW-SSE-oriented bands. When approaching these en échelon bands, the trend of some long grooves (100-150 km) progressively changes, becoming essentially parallel to them (central and northern parts of Fig. 5B).

\subsection{Area E (Molpadia Linea)}

Molpadia Linea is one of the most prominent deformation belts of Lavinia Planitia with a length of more than $1200 \mathrm{~km}$ and a maximum width of around $200 \mathrm{~km}$, and standing up to $700 \mathrm{~m}$ above the surrounding plains (Fig. 6A and B). As a whole, Molpadia Linea has a sigmoid shape, with a NE-SW-directed western branch narrowing towards its southwestern and northeastern tips, and a rectangular, WNW-ESE-oriented central body. The eastern branch of Molpadia, also NE-SW-oriented, ends sharply towards the NE, partly because it is covered by Kaiwan Fluctus young lava flows

Ridge belts are present in and around Molpadia Linea (Fig. 6B). Ridge belts at the western part of the mapped area show sinuous anastomosed traces, excepting the western branch of Molpadia, where they define a straight, NE-SW-trending bundle (Figs. 6 and 7). Apparent truncation of ridge belts by Molpadia Linea can be observed in the central and southern part of the studied area 
A

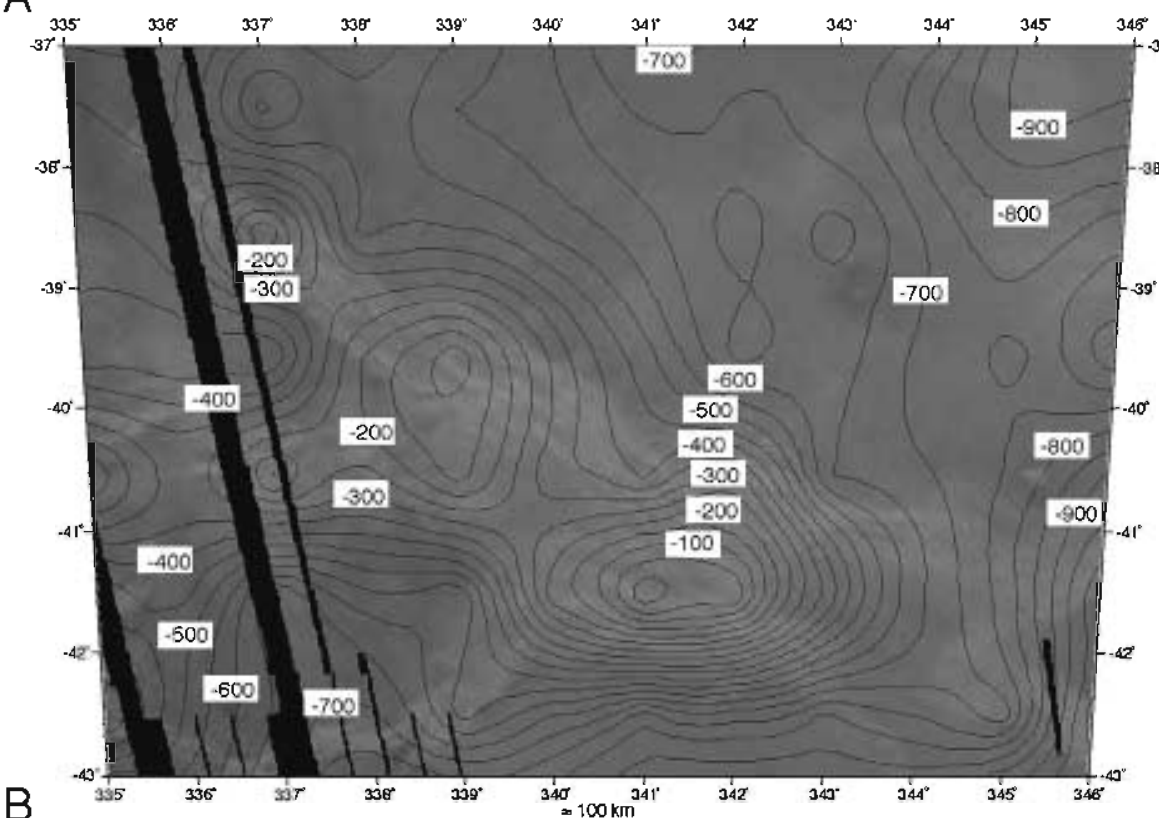

B

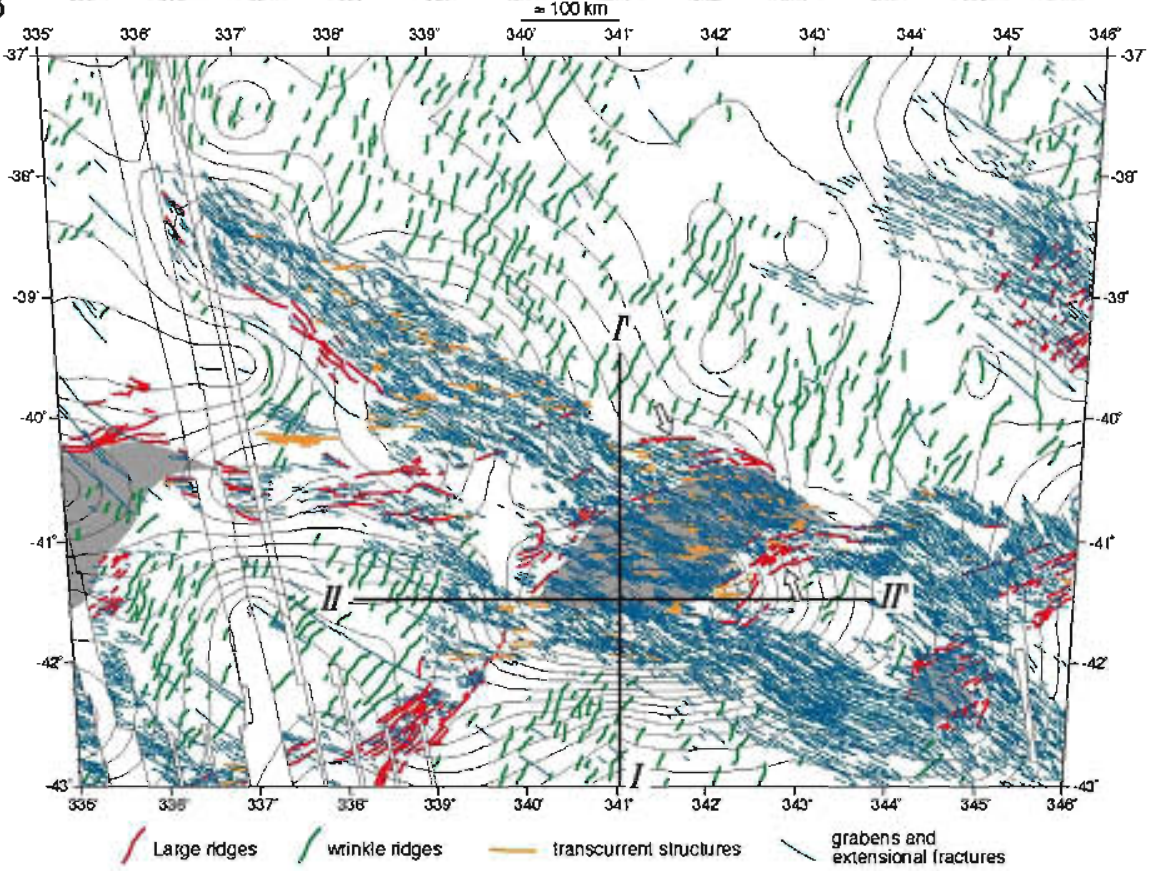

Contractional structures (large ridges)

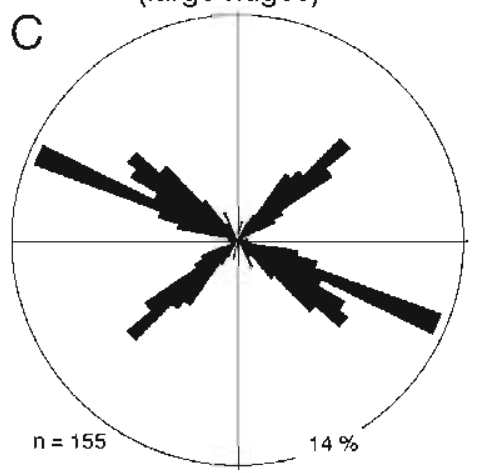

Extensional structures
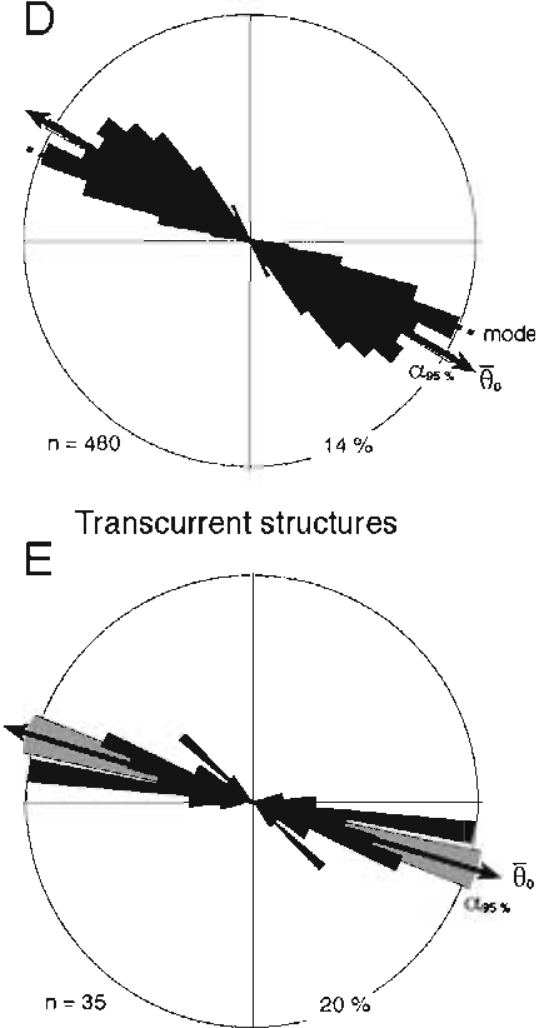

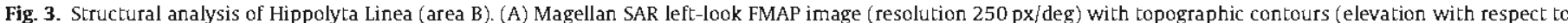

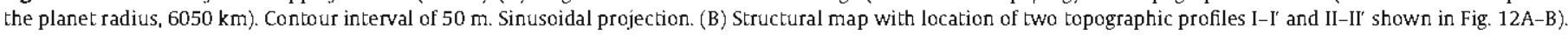

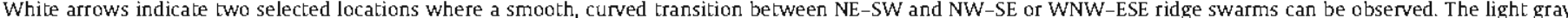

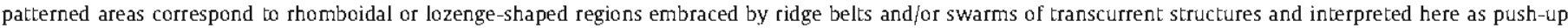

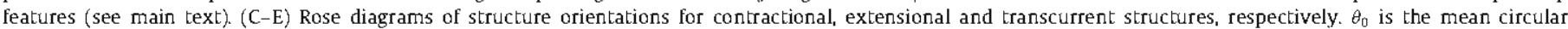

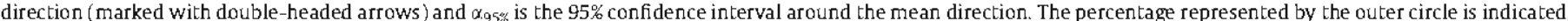
and $n$ is the number of measured features. Bin size is of $5^{\circ}$.

(Fig. 6B). However, it must be stressed that the southern and eastern parts of the mapped area are partly covered by young lava flows (Mylitta Fluctus and Kaiwan Fluctus). Ridge swarms with curved trajectories can be observed at the central area of Molpadia and the northwestern part of the mapped area (Fig. 6B). Spatial patterns of wrinkle ridges are identical to those shown by ridge belts. In fact, wrinkle ridges are often observed in prolongation of larger ridges across the lowlands (Fig. 6B). Computation of the average spacing of wrinkle ridges is thwarted by the cover of young lava flows.
Extensional structures are more complex in Molpadia Linea than in other areas. Very long grooves ( $>300 \mathrm{~km}$ ) can be observed at the northwestern area, locally interspersed with shorter grabens to define irregular NW-SE-oriented fracture belts. These fracture belts curve becoming parallel to the western branch of Molpadia Linea (Fig. 6B and D). Networks of complex crosscutting grabens can be observed at the northern tip of Molpadia Linea and at the northwestern area. Finally, grabens are virtually absent at the eastern half of the mapped area (Fig. 6B), excepting the main body of Molpadia Linea. 

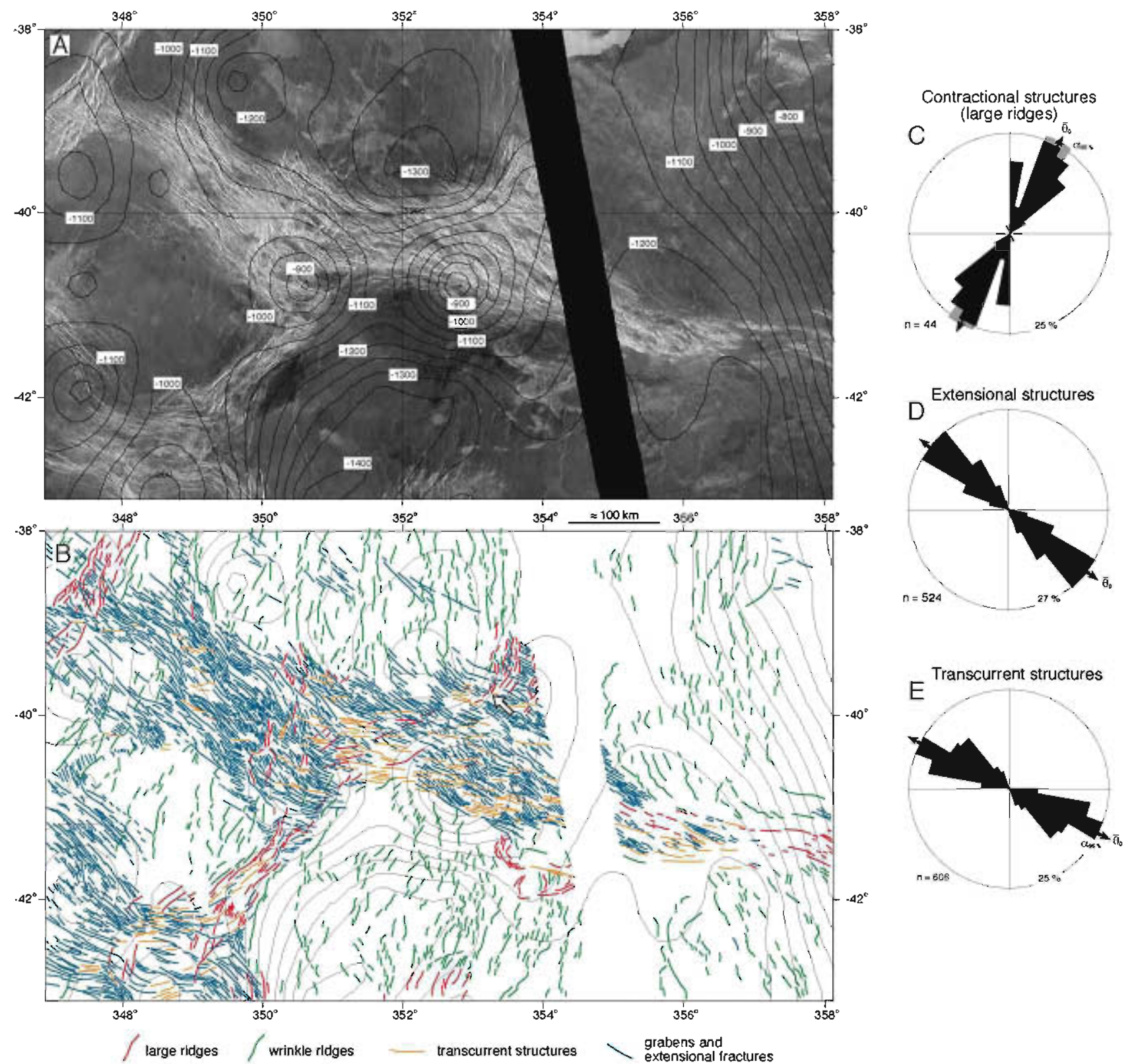

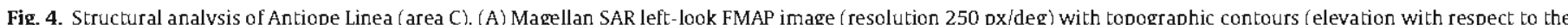

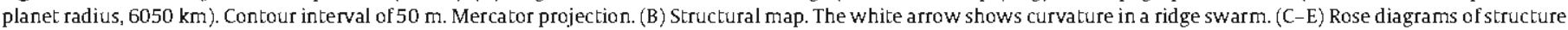

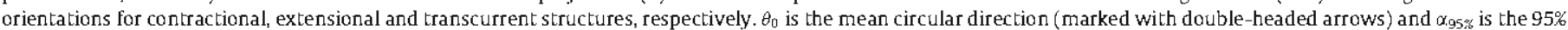
confidence interval around the mean direction. The percentage represented by the outer circle is indicated, and $n$ is the number of measured features. Bin size is of $10^{\circ}$.

The most striking tectonic feature of Molpadia is the huge system of transcurrent structures that outline its western boundary. Compelling structural evidence of strike-slip faulting at this region was presented by Koenig and Aydin (1998) and it will be reinforced in this work. These transcurrent structures of Molpadia are oblique to both the grooves/grabens and the ridges (Fig. 6B-E and enlarged image and rose diagrams of the southwestern subarea at Fig. 7; see also Table 1). Morphologically, these transcurrent structures are marked by swarms of rather straight and often anastomosed fractures that commonly bound lozenge-shaped, less deformed areas, and often appear as a long, elevated relief of an intermediate size between those of large ridges and wrinkle ridges (Fig. 6A, enlarged image). They are typically located at the end of curved and converging swarms of grabens. The NE-SW transcurrent structures of the western boundary of Molpadia Linea curve into E-W to
WNW-ESE-trending structures at the central region and again into NE-SW-directed faults at the eastern branch (Fig. 6B and E). Small tracts of ribbon-tessera terrains can be seen inside Lavinia Planitia. A good example is exposed to the east of the northern subarea (Fig. 7).

Although the average orientation of tectonic structures is shown in Fig. 6C-E and Table 1, the complex internal structure of Molpadia Linea merits a more detailed description. The entire belt has been arbitrarily divided into four main subareas, according to the dominant structures and their average orientation (Fig. 7). At the southwestern area, $\mathrm{N} 51^{\circ} \mathrm{E}$-oriented ridges (Table 1 ) are disposed at a low angle to the prominent $\mathrm{N} 61^{\circ} \mathrm{E}$-trending transcurrent segments described by Koenig and Aydin (1998) and in this work Transcurrent structures embrace less fractured, lozenge-shaped areas (Fig. 7) with maximum lengths of less than $100 \mathrm{~km}$. Grabens 

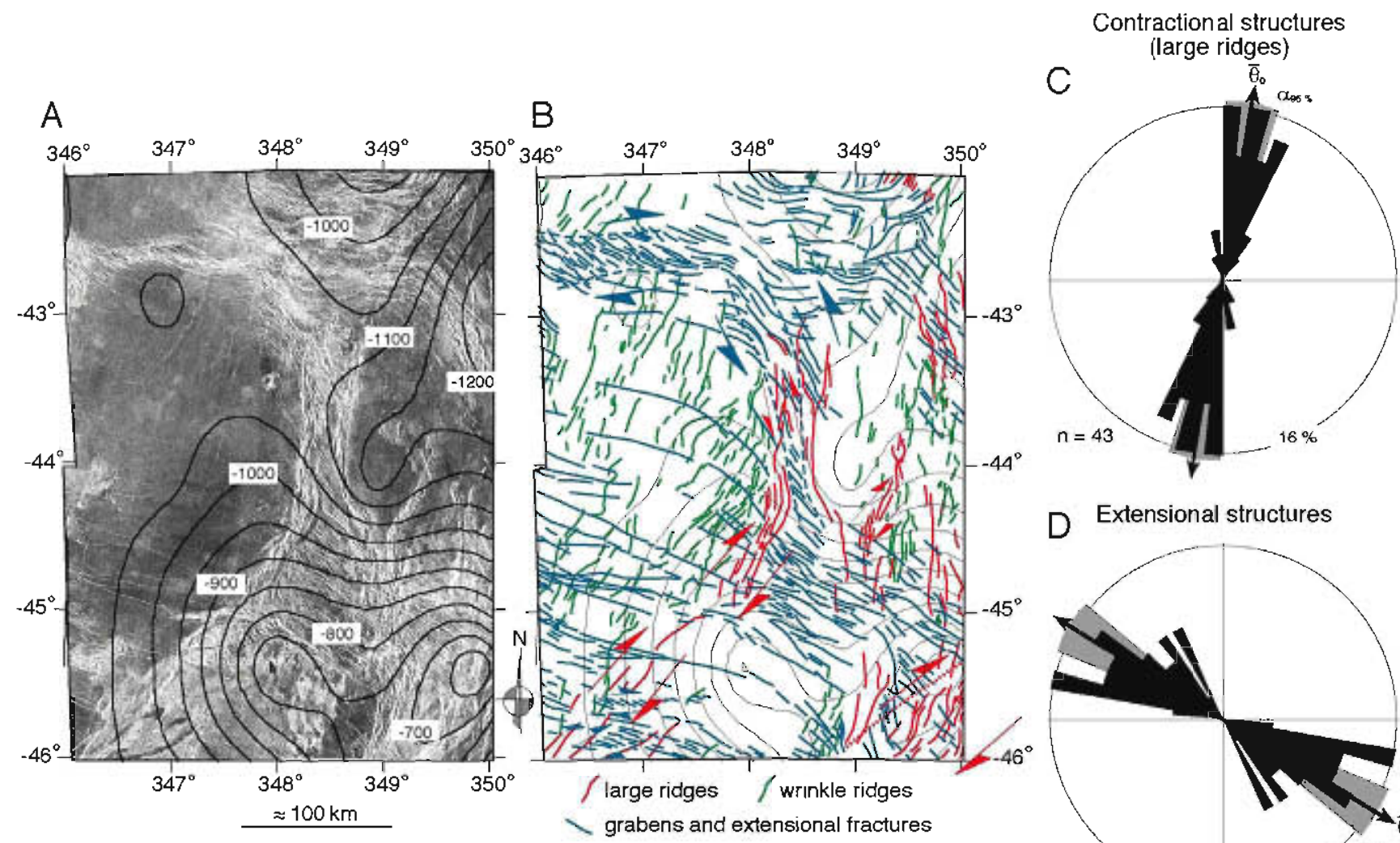

D Extensional structures

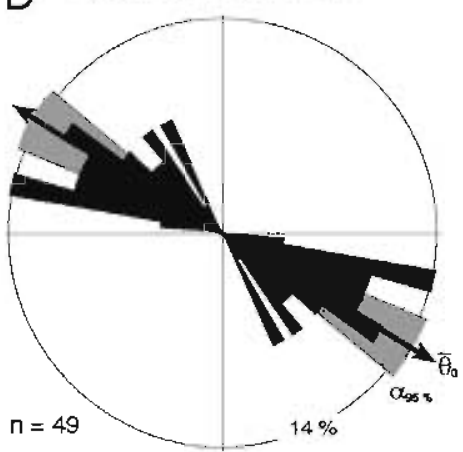

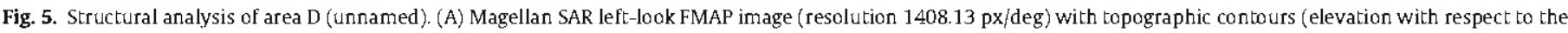

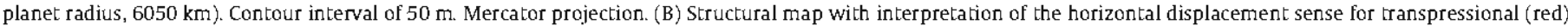

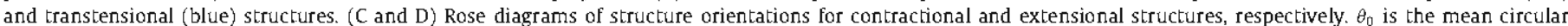

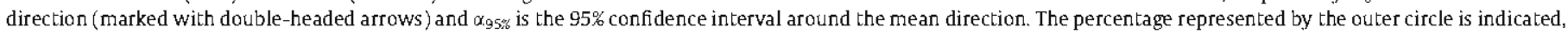
and $n$ is the number of measured features. Bin size is of $5^{\circ}$.

are mostly oriented $\mathrm{NW}-\mathrm{SE}\left(\mathrm{N} 125^{\circ} \mathrm{E}\right.$, Table 1 ), although their curving geometry results in a NE-SW-oriented mode at the rose diagram (Fig. 7). The northern area is by far the more complex. Orientation of contractional structures there show several modes (Fig. 7), and a dense cortege of NNW-SSE-directed grabens crosscut apparently older E-W to WNW-ESE grabens. By contrast, the central area of Molpadia is simpler (Fig. 7). Ridges are slightly curved and show an average N53 ${ }^{\circ} \mathrm{E}$ trend (Fig. 7, Table 1). Grabens are $\mathrm{NW}-\mathrm{SE}$-oriented $\left(\mathrm{N} 131^{\circ} \mathrm{E}\right.$, Table 1$)$ and, together with transcurrent structures $\left(\mathrm{N} 94^{\circ} \mathrm{E}\right)$, embrace elongate WNW-ESE-oriented less fractured zones (with maximum lengths of $100 \mathrm{~km}$ ). The structures of the northeastern area are obscured by the young lava flows. Extensional structures are here subordinated to the ridges (N53 ${ }^{\circ}$, Table 1) and transcurrent structures (N84 ${ }^{\circ} \mathrm{E}$ ).

\subsection{Area $F$ (Penardun Linea)}

Penardun Linea is located at the southern part of Lavinia Planitia. The northwestern part of the mapped area includes the southern prolongation of Molpadia Linea (Fig. 8A and B). Ridges at Penardun are mostly curved and arranged in en échelon, rightstepped patterns. Well-developed stepped ridges that converge on a common NE-SW-oriented ridge (marked by arrows in Fig. 8B) can be observed at the central part of the mapped area. Ridge belts (and individual ridges within them) are curved and disposed in an anastomosed pattern (Fig. 8B), which gives place to a multimodal distribution of orientations (Fig. 8C). They pass laterally into ENE-WSW transcurrent structures (Fig. 8B and E). Calcu- lation of interlimb angles for individual ridges following the procedure developed by Ghert and Hansen (1999) mentioned in area $A$ yield similar large values of $170-175^{\circ}$. Wrinkle ridges continue the general pattern of larger ridges in the low-lying plains. Ridges, wrinkle ridges and transcurrent structures embrace large (average length of long axes is of 100-150 km), sigmoid, lozengeshape, less-deformed regions, also arranged en échelon (the approximate centers of these regions are marked with asterisks in Fig. 8B). Grooves and graben systems cross Penardun and the southern tip of Molpadia from NW to SE, describing a large-scale, S-shaped structure. This geometry is the result of the strike-slip component of displacement along Molpadia and Penardun, and it explains the multimodal distribution of orientations (Fig. 8D). The described structures are partly covered at the southeastern corner of the mapped area by the lava flows of Mylitta Fluctus.

\section{Discussion}

\subsection{Interpretation and structural evolution}

Kinematic interpretation of the Lavinia Planitia deformation belts requires a detailed analysis of the geometrical characteristics of their predominant structures. Sigmoid, en échelon arrangement of ridges is a typical feature of structures generated under an important component of strike-slip displacement (e.g., Sylvester, 1988). Fig. 9 shows an enlargement of the ridges located at the southern part of area A Identical structures have been obtained 

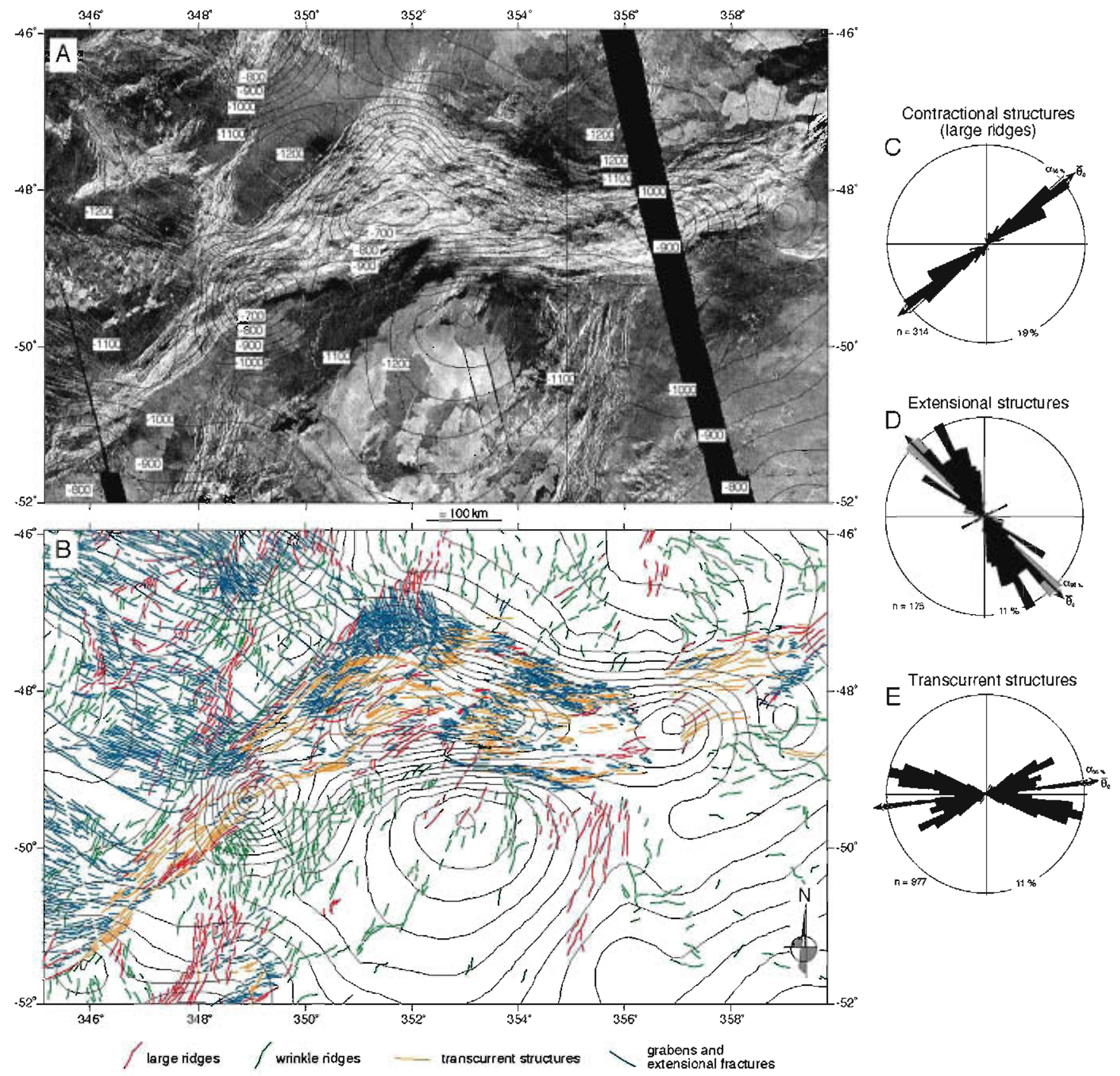

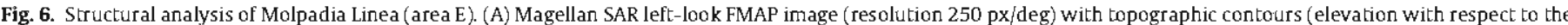

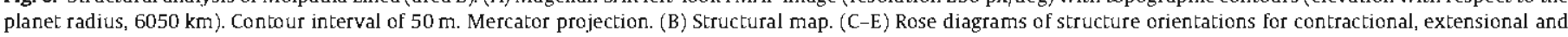

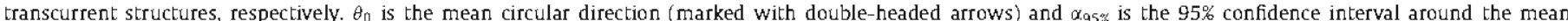
direction. The percentage represented by the outer circle is indicated, and $n$ is the number of measured features. Bin size is of $5^{\circ}$.

by Richard et al. (1991) in their experimental analysis of folding under strike-slip faulting (Fig. 9A and B). Digitate terminations of folds in the experiment shown in Fig. 9 A are very similar to the closures of ridges at the location marked with an asterisk. Natural examples on Earth show similar characteristics (Fig. 9C and E). From the right-stepping of ridges at area A (Fig. 9 for the central belt, and white arrows in Fig. $2 \mathrm{~A}$ for the distinct ridge belts of this area) it can be concluded (Fig. 9D) that the region was subjected to a dextral strike-slip component of displacement (Fig. 2B). The same interpretation can be suggested for several dextral bands at area D (Fig. 5B). On the other side, long, straight, parallel ridges in the central part of area D (Fig. 5B) can be better explained as due to shortening normal to the ridge traces.
Extensional fracture belts also show evidence of both, orthogonal and oblique extension. This assertion is best illustrated by the geological sketch of an enlarged sector of area A (Fig. 10). Long, parallel grabens are observed at the western part of the sketch (Fig. 10A). The circular mean of graben trends is $N 125^{\circ} \mathrm{E}$ (Table 1), sub-parallel to the rift axis at this area (Fig. 10B). Experimental patterns of normal faults generated under orthogonal extension (McClay et al., 2002) show an excellent agreement with those represented in Fig. 10A (Fig. 10E and F). Therefore, this zone can be interpreted as due to extension normal to the rift axis (open arrows in Fig. 10A). Analogously, the grabens at the central and northern part of area $A$ can be interpreted as due to orthogonal extension (Fig. 2B), as well as most of the Hippolyta rift 


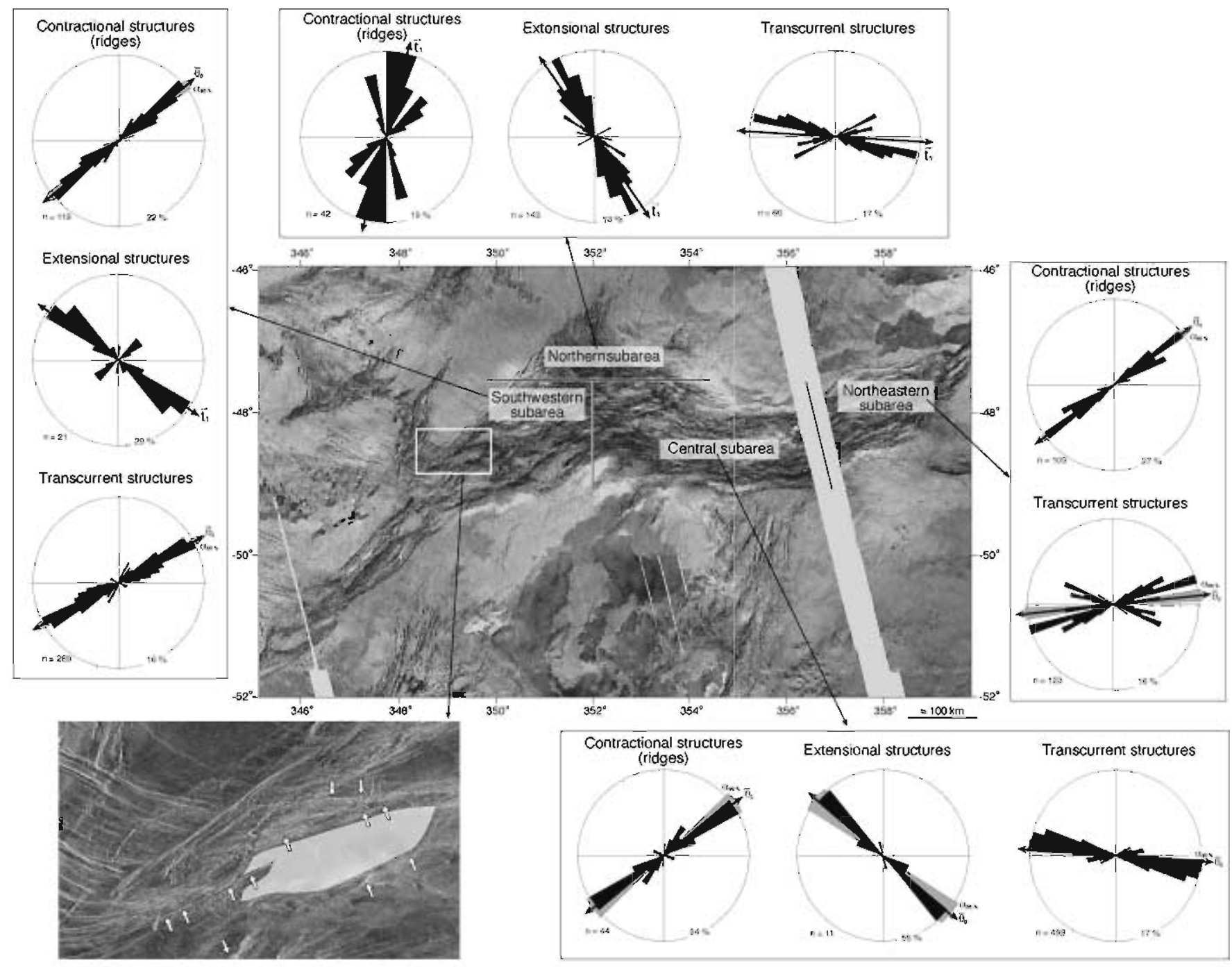

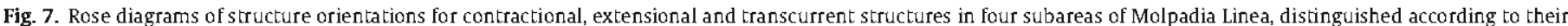

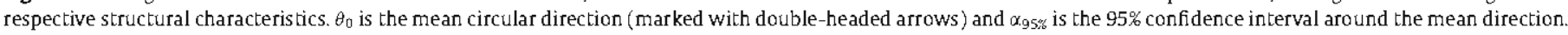

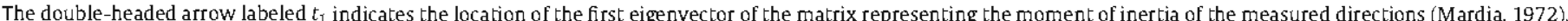

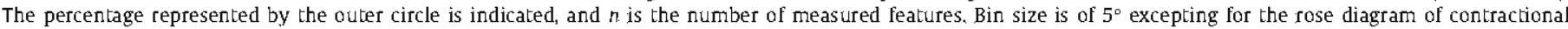

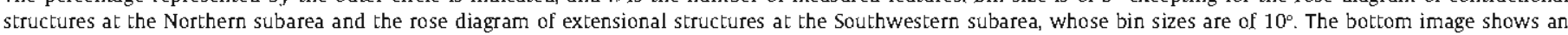

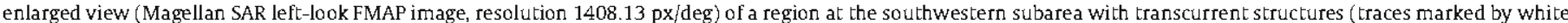
arrows) and lozenge-shaped areas bounded by them (shaded region).

(Fig. 3B) and the western part of Antiope Linea (Fig. 4B). However, the zone located at the eastern half of the mapped area (Fig. 10C) shows curved, sigmoid grabens arranged en échelon. Right-stepping and obliquity between the circular mean of their trends (N119 ${ }^{\circ} \mathrm{E}$, Table 1, Fig. 10D) and the strike of the rift axis at this point ( $\sim$ E-W, Fig. 10C) allow comparison of this pattern with that obtained under dextral oblique extension by McClay et al. (2002) (Fig. $10 \mathrm{G}$ and $\mathrm{H}$ ). Also, the natural case of the Gulf of Aden (Fig. 10I and J), described by Dauteuil et al. (2001), is comparable in geometry and scale with Fig. 10C. Therefore, this zone can be interpreted as a consequence of dextral, oblique extension (open arrows in Fig. 10C). Indeed, the trace of one ridge is observed displaced for around $5 \mathrm{~km}$ in a dextral sense (indicated by the small arrow at Fig. 10C; a SAR image of this area at the maximum available resolution is also shown to the right of Fig. 10C). oblique extension can also be mentioned as the best explanation for some sectors at the center and northeastern branches of Hippolyta rift (mostly dextral shear along the transcurrent structures, Fig. 3B), at the central part of Antiope Linea (the right-stepped geometries limited by transcurrent structures indicating dextral shear, Fig. $4 B$ ), at area $D$ (dextral oblique extension at the northern and southern part of this area, and sinistral at the center, Fig. 5B), at Molpadia Linea (Fig. 6B, apart from the structures described by Koenig and Aydin, 1998), and at Penardun Linea (Fig. 8B).

of special interest is the anastomosed pattern of ridge belts and bundles of wrinkle ridges observed all around Lavinia Planitia embracing less-deformed, lozenge-shaped regions (Figs. 3 and 8B). Some particularly neat cases are represented in Fig. 11 (A: Penardun Linea and south of Molpadia Linea; B: area D and northwestern Molpadia Linea). The less-deformed regions are marked with a reddish pattern. It can be observed how these regions are outlined by ridges, wrinkle ridges and transcurrent structures. The geometry of these regions corresponds to that shown by push-ups generated at restraining stepovers (e.g., Woodcock and Schubert, 1994). Similar geometries (Fig. 11C) have been mapped in the Precambrian Brazilian craton by Davison and Powell (1991) and Ebert and Hasui (1998). The relationship of these structures 

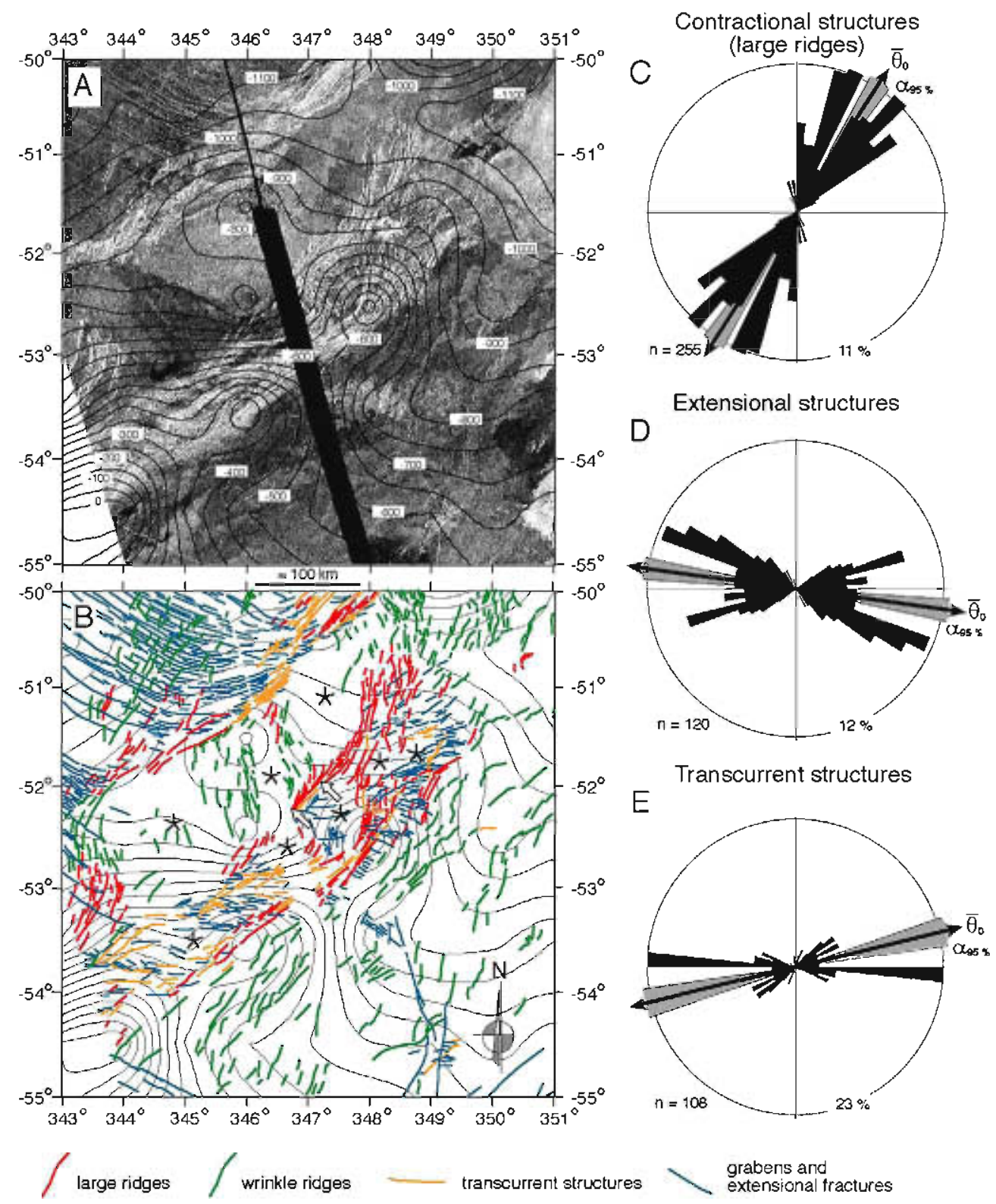

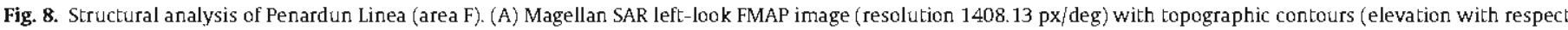

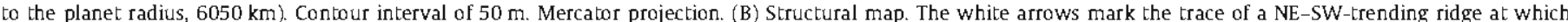

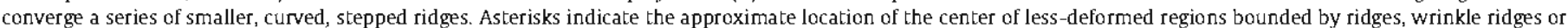

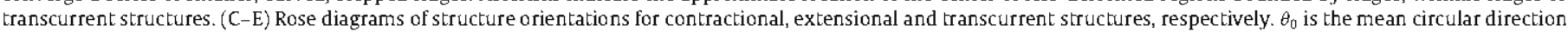

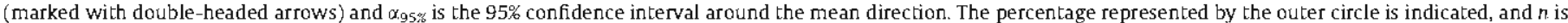
the number of neasured features. Bin size is of $5^{\circ}$.

with the topography offers additional information for their interpretation. Two topographic profiles (labeled I and II in Fig. 3B) crosscutting a possible push-up structure at Hippolyta Linea (marked with a light gray pattern in Fig. 3B) show that this region stands as a topographic high (Fig. 12A and B), with the deformation bands (ridge belts and transcurrent structures, doubleheaded arrows at Fig. 12) located at its slopes. Profiles III (Fig. 12C) and IV (Fig. 12D) show the topographic expression of several adjacent rhomboidal areas at Penardun Linea and area D, respectively. The individual rhomboidal areas appear commonly with positive relief and limited by deformation bands. The region covered by the distinct adjacent rhomboidal areas remains as a topographic high relative to the nearby less deformed lowlands (Fig. 12C and D). Therefore, these large structures can be interpreted as a result of dextral transpression in most of the studied areas (Fig. 11A and B). Fig. 13 shows the traces of the main ridges and ridge belts, and the large interpreted push-up structures on a topographic map of Lavinia Planitia. It can be observed how some of the main reliefs of Lavinia are mainly conditioned by the location and trend of ridge belts and push-ups. Apparently, the topographic expression of extensional structures is secondary with respect to the large control exerted by the contractional features. Topographic profiles show a large-scale, SWdirected slope (Fig. 12E), already described by Ivanov and Head (2007). Also evident in the profiles is the topographic record of the large ridge belts and push-ups (Fig. 12F-H).

Kinematic analysis of the studied areas has allowed us to characterize the orientation of the principal deformation axes in the horizontal (e.g., principal shortening axis, marked with large arrows in Fig. 11A and B). Results are shown in Fig. 14, which 


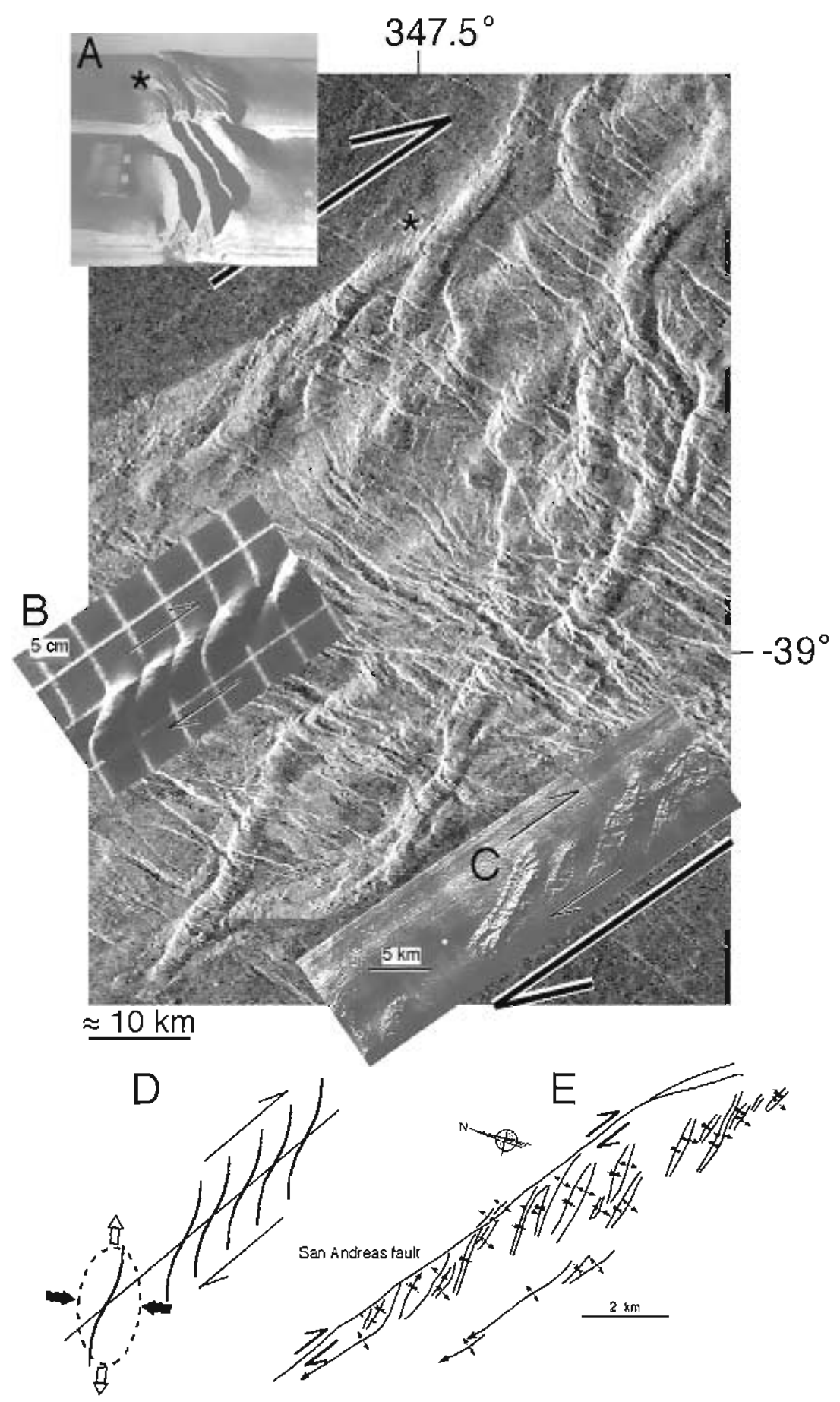

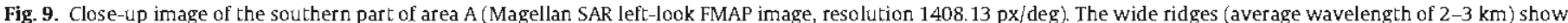

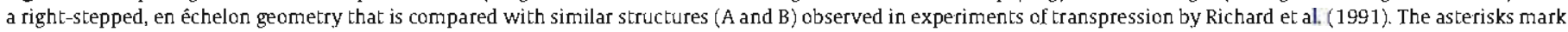

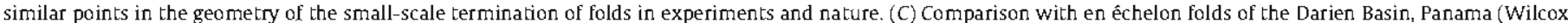

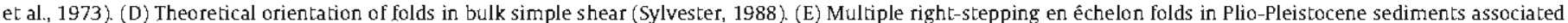
with the San Andreas fault near the Salton Sea (modified from Dibblee (1977) and Sylvester (1988)). In all cases the strike slip component is dextral.

represents the orientation of the horizontal principal shortening axis (symmetric arrows) for most of Lavinia Planitia. Changes in the strike of deformation belts favors lateral variation from orthogonal extension to transtension (e.g., Antiope Linea, Fig. 4), from orthogonal contraction to transpression (e.g., area D, Fig. 5) or from transpression to transtension (e.g., Molpadia Linea, Figs. 6 and 7). This observation was also noted by Squyres et al. (1992). The horizontal shortening field for contractional and transpressional structures is distinguished in Fig. 14 from the hor- izontal shortening field for extensional and transtensional structures.

The available information is not conclusive about the age relationships between extensional structures and ridge belts. However, given the fact that ridges and extensional fractures tend to be statistically perpendicular (rose diagrams in Figs. 2-8 and Table 1), it cannot be discarded that both types of structures could be broadly synchronous. Ridge belts are mostly older than the lavas forming the lowlands (e.g., Fig. 3). Wrinkle ridges are generally younger 

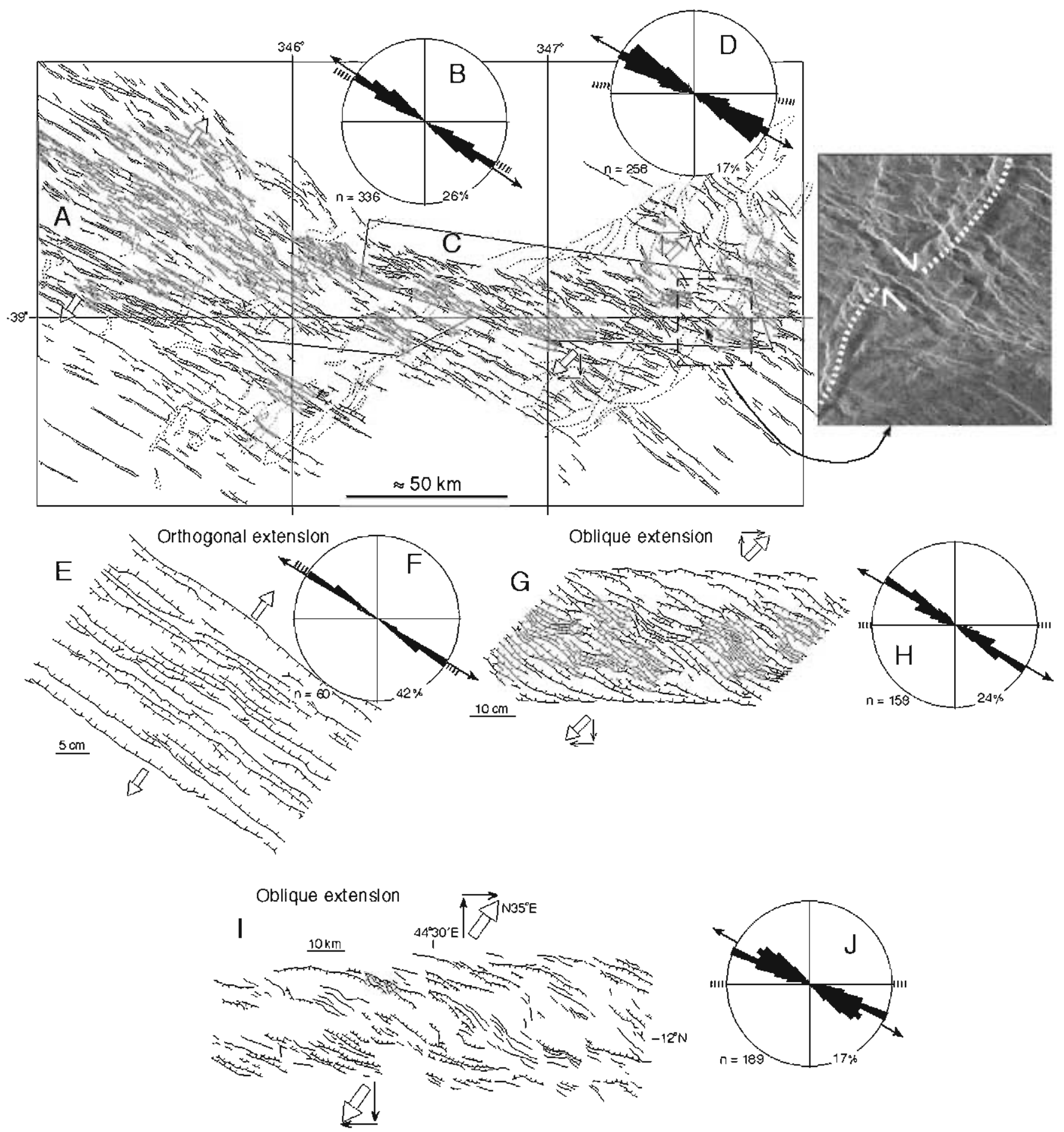

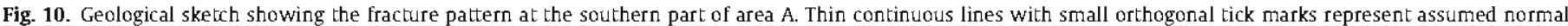

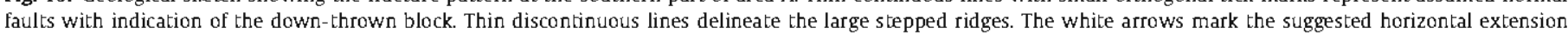

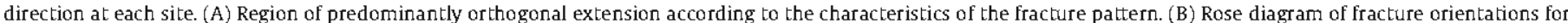

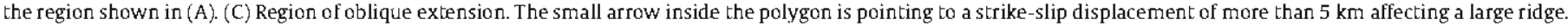

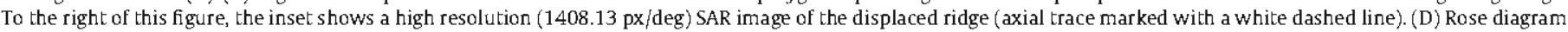

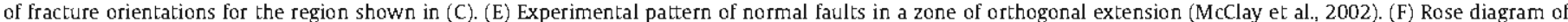

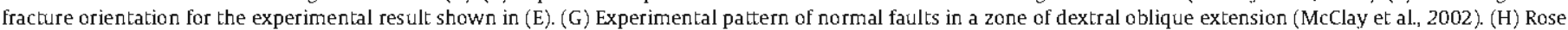

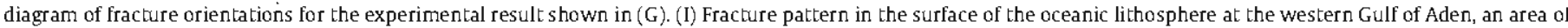

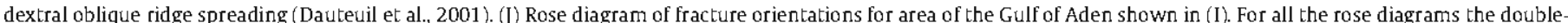

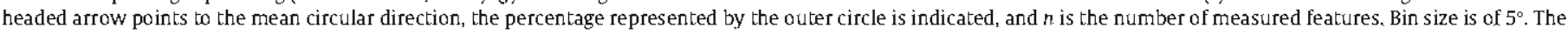

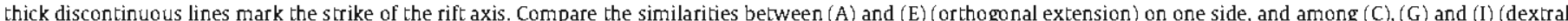

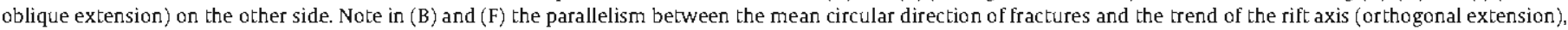
and the obliquity bewween both elements in (D), (H) and (I) (oblique, dextral extension).

than ridge belts (Fig. 3). Therefore, the tectonic evolution of Lavinia involves at least two stages, probably separated in time (Ivanov et al., 2000). During the first stage, mostly previous to the material of the plains, transcurrent structures developed contemporarily 


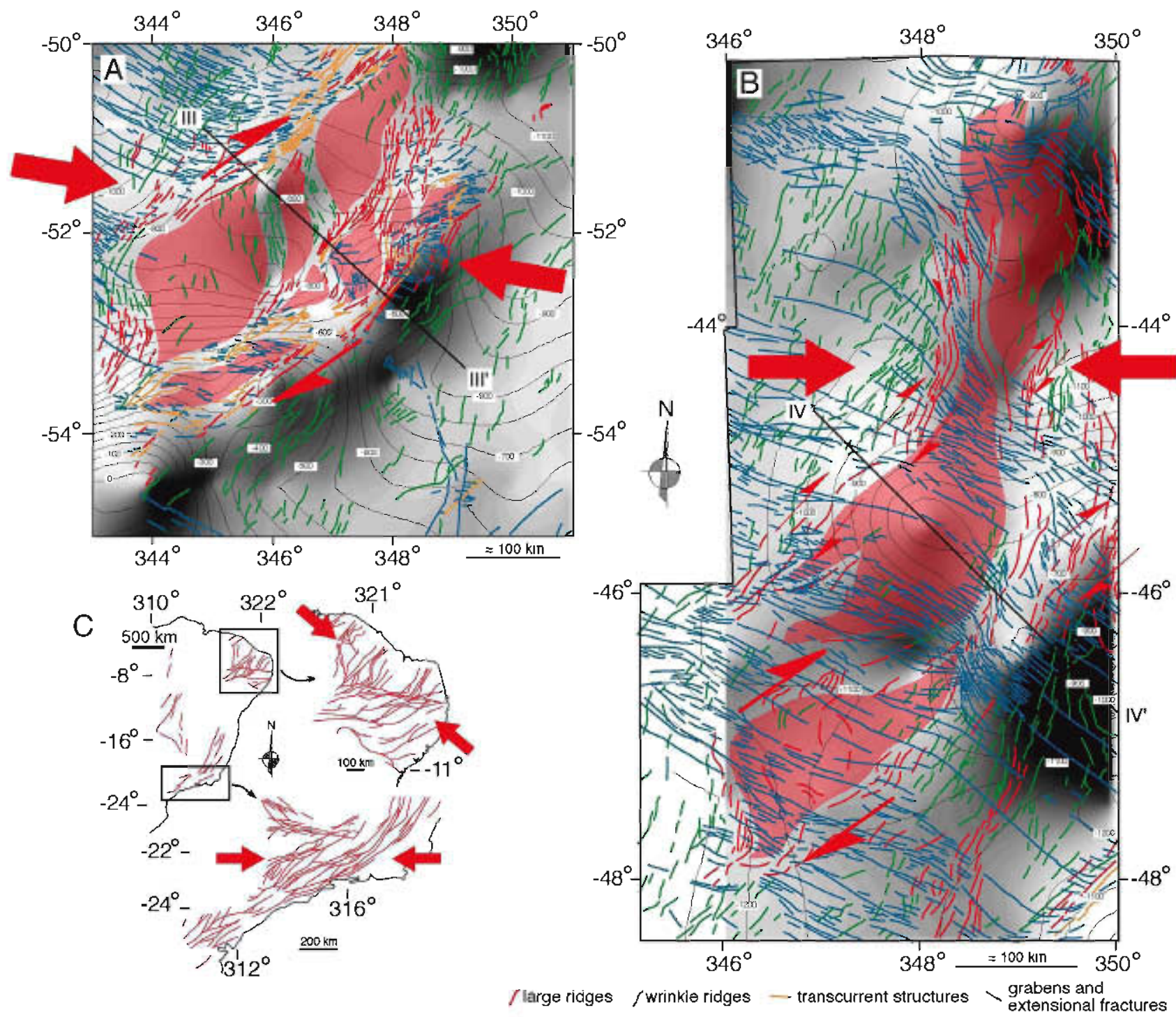

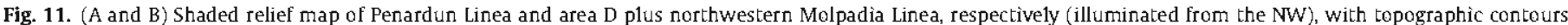

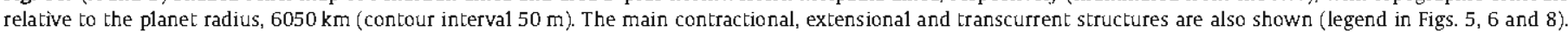

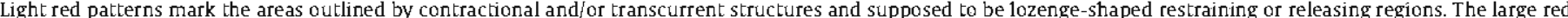

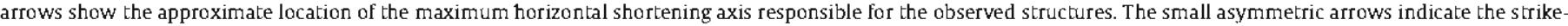

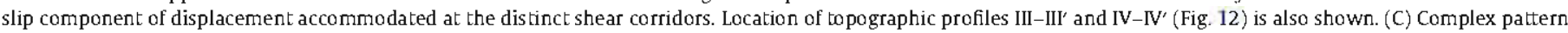

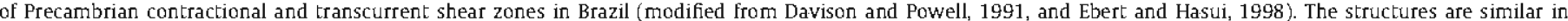
geometry and size to those observed at Lavinia Planitia. Again, the red arrows show the approximate location of the maximum horizontal shortening axis.

with both contractional (transpression zones) and extensional (transtension zones) belts. Lateral passage from contractional to transcurrent and then to extensional belts is commonly observed. The second stage, mostly later than the material of the plains, gave place to wrinkle ridges and some extensional fractures. Volcanic activity probably occurred during the first stage, although large areas in the lowlands were covered by lava flows between both stages, and also during the second stage and later. The deformation field of the first stage remains identical with independence of the type of structure (extensional, transcurrent or contractional) used to define (Fig. 14). This coincidence of the trend of shortening axis was already suggested by Squyres et al. (1992). The strain interpretation of the broad area of Lavinia offered by Hansen (2007) shows a bulk strain ellipse with shortening axis oriented NW-SE, which is consistent with the general pattern shown in Fig. 14. What is new from this work is the concentric, near-circular pattern described by both deformation fields (Fig. 14). Although some uncertainty remains in the location of the shortening axes determined from contractional structures at the northwestern part of Lavinia due to their comparatively poor exposure, the whole near-circular pattern seems well marked. The common center of curvature is located at Alpha Regio $\left(\sim 23^{\circ} \mathrm{S}, 2^{\circ} \mathrm{E}\right)$. Neither the orientation of the deformation belts nor the fields depicted by the principal shortening axis are easily interpreted as due to a downwelling process focused on Lavinia Planitia. Instead, the origin of this tectonic evolution exceeds the size of Lavinia and it seems centered outside this region. Interestingly, the coordinates of the estimated center of curvature of both deformation fields coincide with the highest elevation at the NE corner of Lavinia (Fig. 12E). Any tectonic model of Lavinia Planitia must consider the relations shown in Fig. 14, as well as the compatibility of the deformation field under contemporary contractional and extensional settings. 

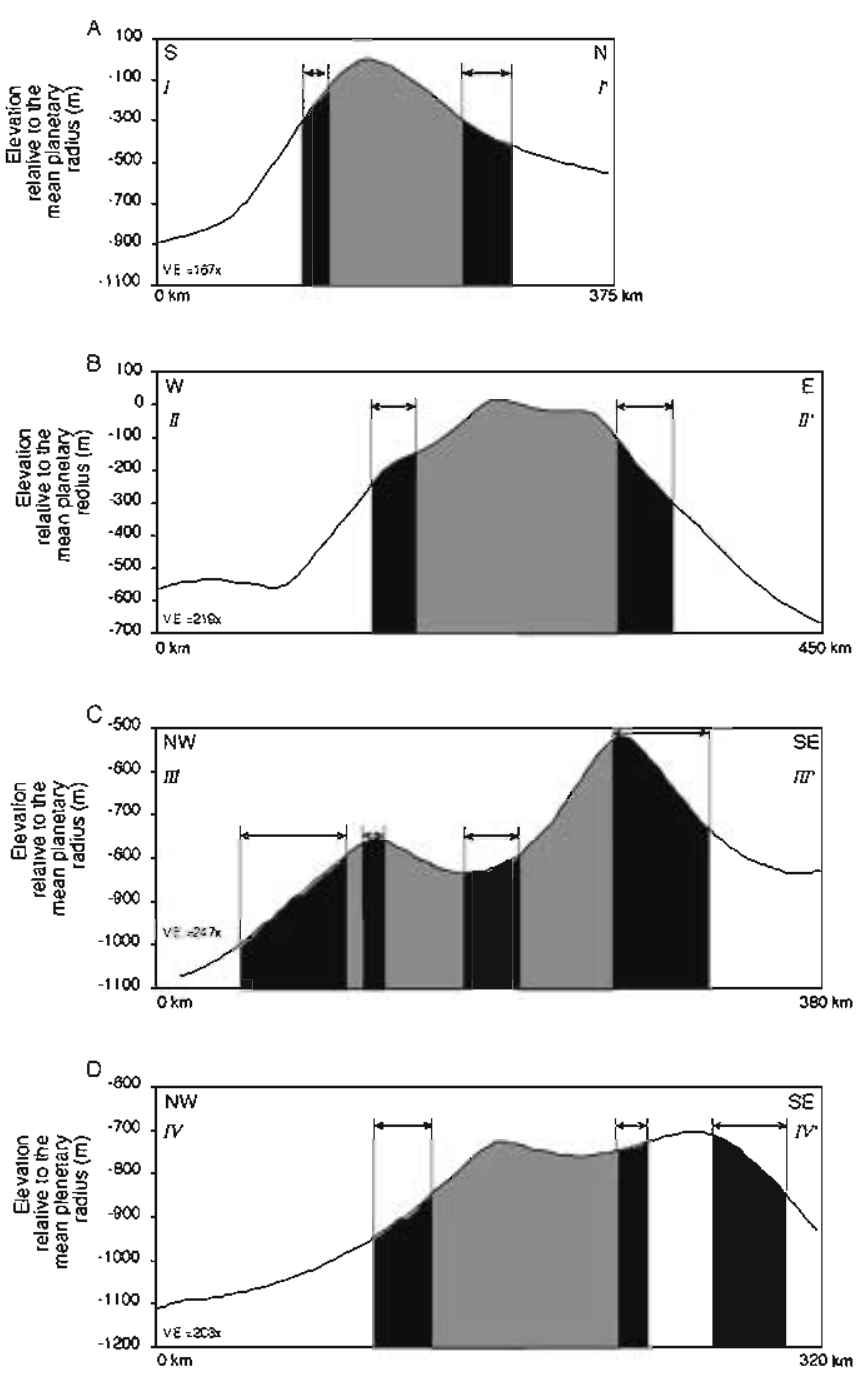
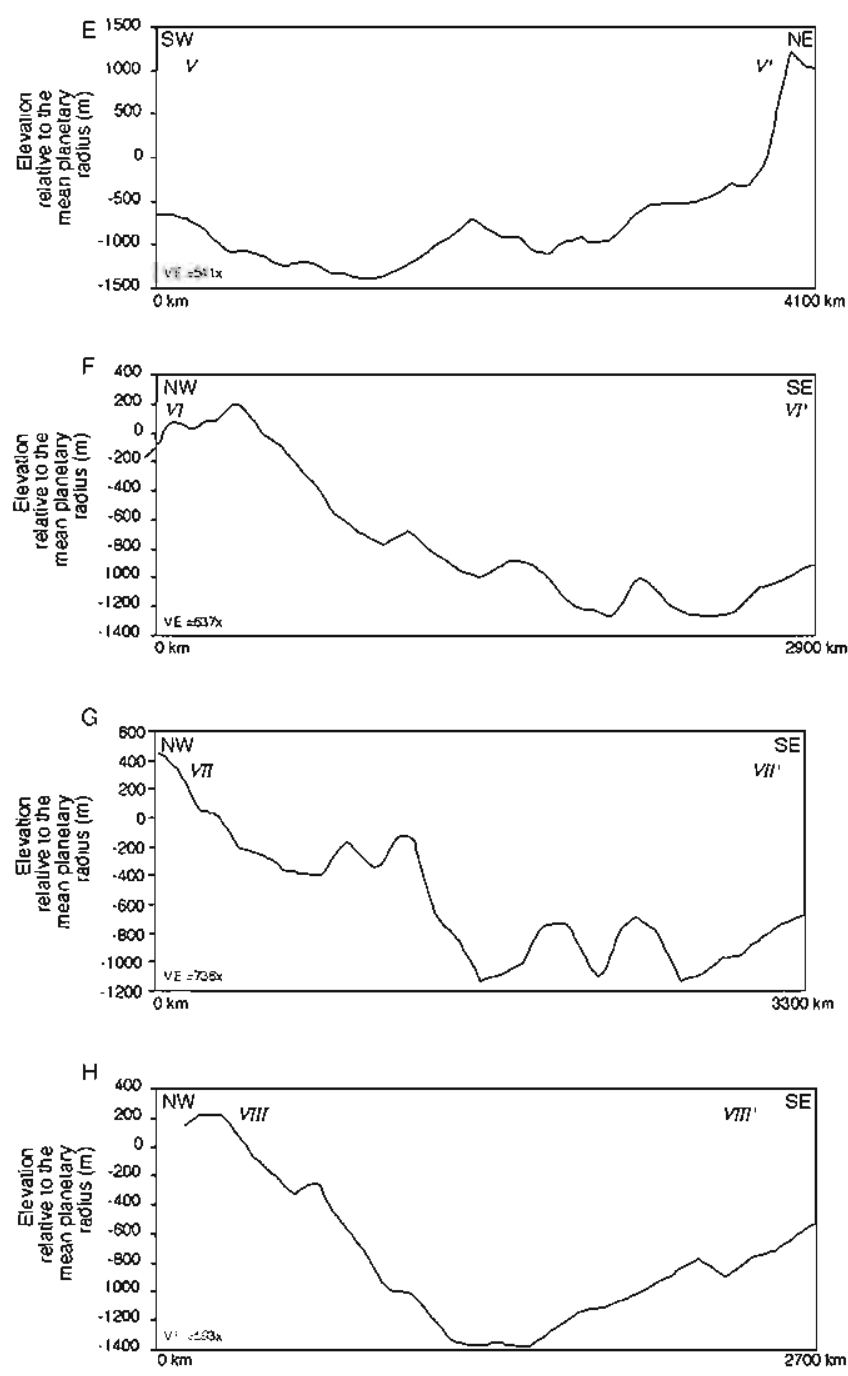

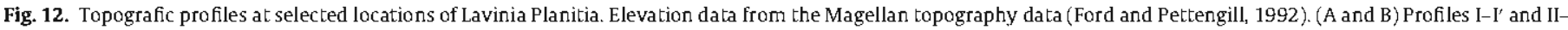

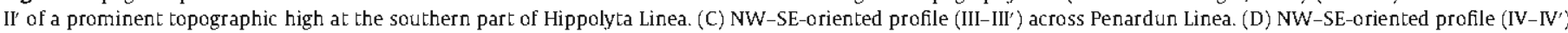

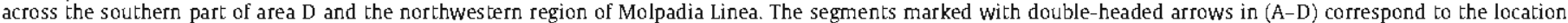

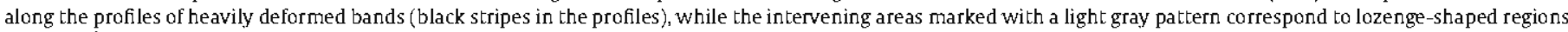

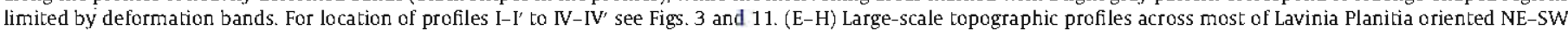

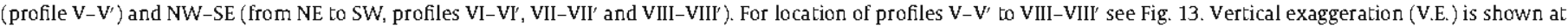
each profile.

\subsection{Recognition and significance of strike-slip components of displacement}

It has been shown in this work that lateral displacement components are present in most, if not all, the studied deformation belts. There seems to be a resistance in planetary geology to recognize strike-slip faults in planets outside the Earth. Three main reasons can be advanced to explain this resistance. First, strike-slip displacements are very difficult to identify, even on Earth (Moody and Hill, 1956; Sylvester, 1988), and this is particularly clear when imagery data are the main, if not the only, source of information available for structural interpretation. It is useful to remind that before the decade of 1950 many structural geologists rejected the idea of large strike-slip displacements on Earth (Sylvester, 1988). In a now classical study, Moody and Hill (1956) suggested six criteria to recognize wrench faults. Four of these can be evaluated from data gathered from planets outside the Earth: straight traces, offsets in structures (or streams in planets like Mars), orientation of minor associated structures, and en échelon faults or anticlines. Several of these criteria are observed at Lavinia Planitia and have been used in this work to establish the activity of strike-slip components of displacement at most of the analyzed deformation belts. Only slickenside observation and careful sedimentary studies remain elusive in the kinematic analys is of faults outside the Earth, although the recent missions to Mars are challenging this assertion. Second, tectonic regimes show all the intermediate cases among pure extensional, contractional and transcurrent settings. Transpressional and transtensional tectonics constitute a realm of complex kinematic patterns whose characterization constitutes a central line of research in modern structural geology (e.g., Holdsworth et al., 1998). Large lateral displacements can be accommodated through en échelon arrays of normal or reverse faults and folds in narrow elongate zones (Sylvester, 1988; McClay et al. 2002). Therefore, the presence of pure normal or reverse faults dominating a given zone does not exclude the activity of relatively important lateral displacements. And third, strike-slip fault is not synonymous of transform fault (e.g., Twiss and Moores, 1992). Often the identification of strike-slip faults is rejected under the argument that no evidences of plate tectonics have been found for that epoch and planet. However, transcurrent displacements 


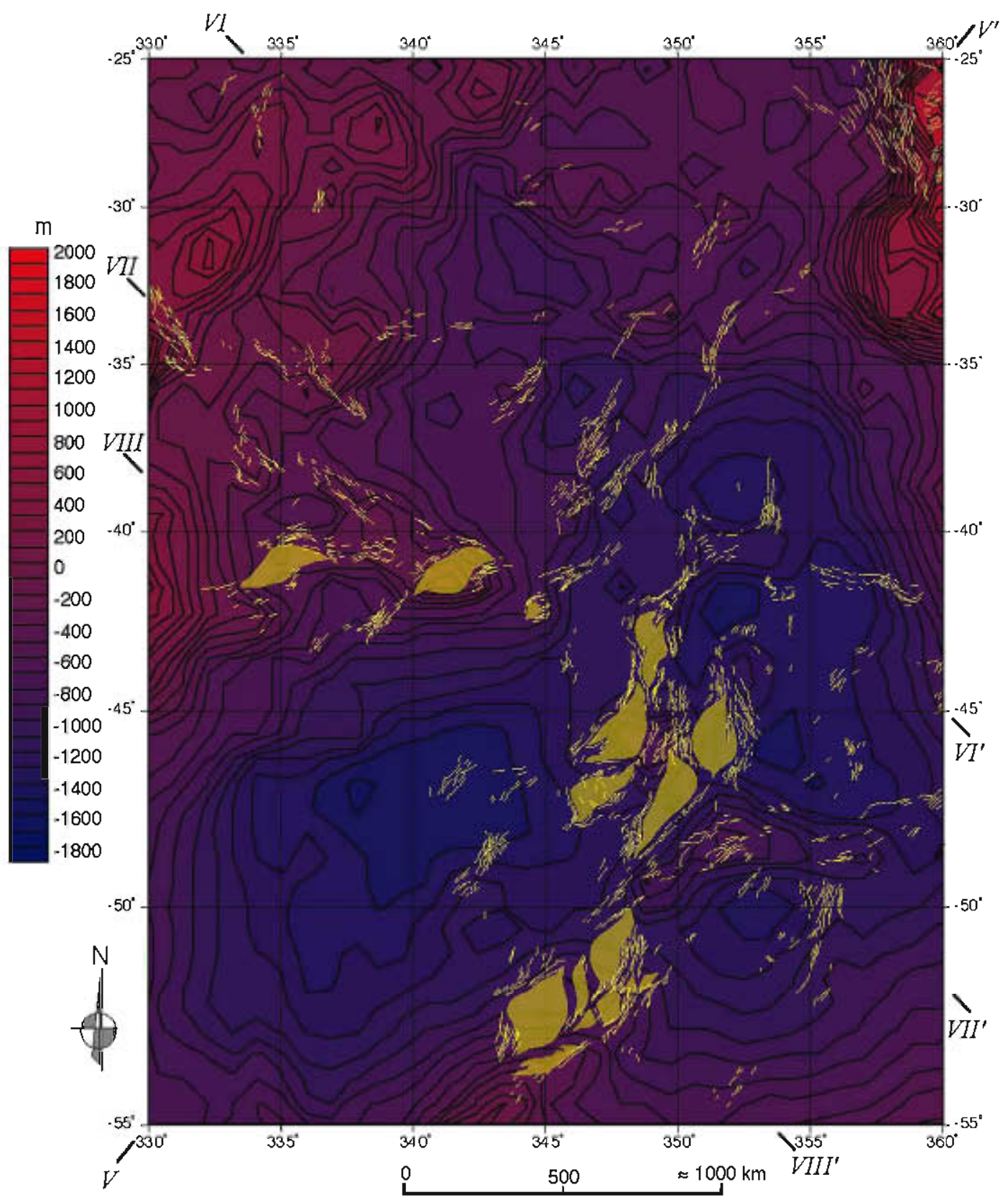

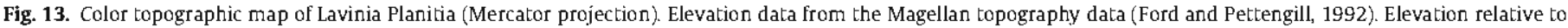

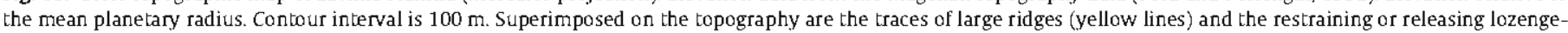

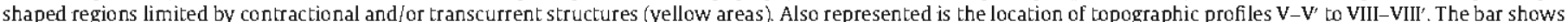
the scale at the center of the map.

can result from lateral accommodation of large extensional or contractional structures, including escape tectonics. They can also act as tear and transfer zones (Woodcock and Schubert, 1994), and are an inescapable result of the reactivation of older structures (Fernández and Anguita, 2007). None of these local or regional scenarios need a global-scale plate tectonics setting.

In conclusion, it can be predicted that pure strike-slip faults or lateral displacement components in complex deformation zones will be increasingly observed and characterized in the planetary bodies of the Solar System. Identification of this type of displacement component is essential to improve our kinematic interpretations and the available tectonic and theoretical models of driving forces on Venus.

\section{Geodynanic implications}

For Magee and Head (1995) Lavinia's quasi-circular geometry reflects a cylindrical downwelling. However, the structural evidence presented in this work does not support a cylindrical downwelling of Lavinia alone. The orientation of the contractional structures at Lavinia Planitia also contrasts with the predictions of the swell-push model. The absence of evidences for marginal extension at the contractional belts of Lavinia Planitia (Figs. 2-8) is in conflict with the delamination process as originally proposed by Young and Hansen (2005) for Poludnista Dorsa. However, local delamination cannot be ruled out for some belts, where syntectonic volcanism was apparently intense (e.g., Hippolyta Linea), 


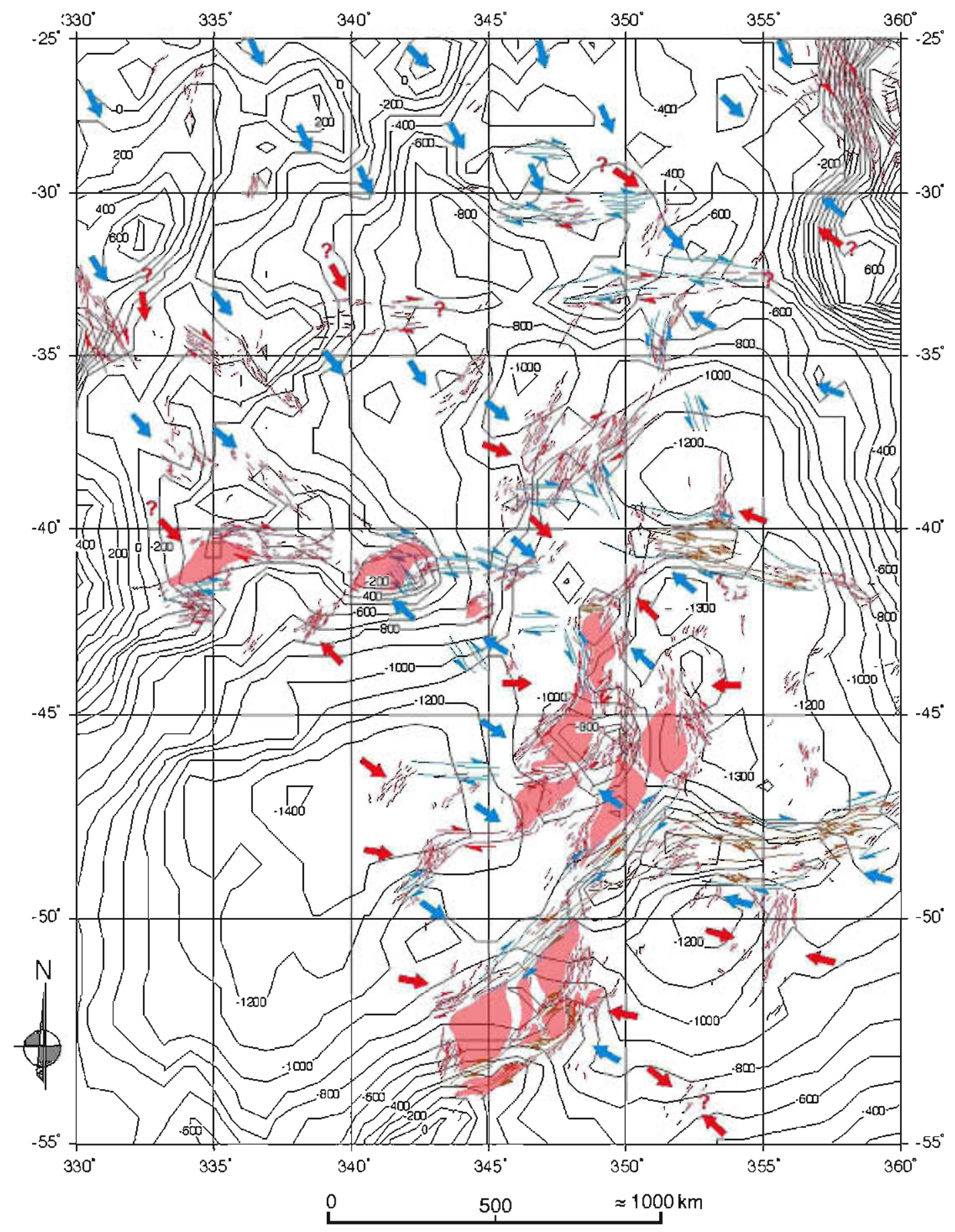

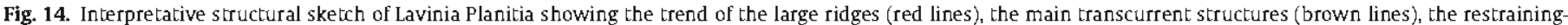

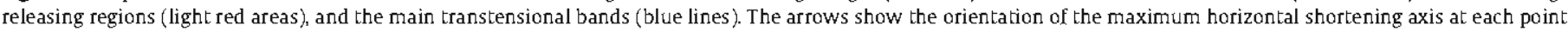

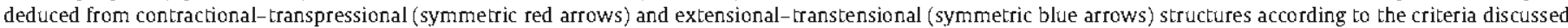

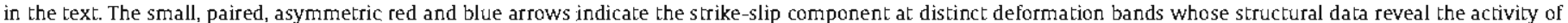

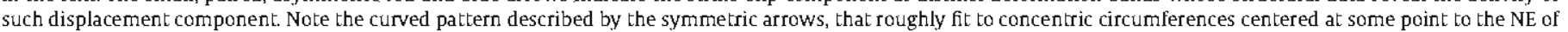

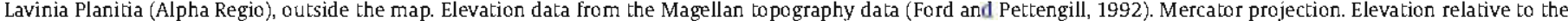
mean planetary radius. Contour interval is $100 \mathrm{~m}$. The bar shows the scale at the center of the map.

although probably in association with another kind of major driving force.

Analyses of the gravity and topography of the Venusian plains were qualitatively and quantitatively interpreted to be consistent with the downwelling hypothesis (e.g., Bindschadler et al., 1992; Lawrence and Phillips, 2003). The results of Anderson and Smrekar
(2006) indicate a complex lithospheric structure for the Lavinia Planitia region, with a weaker lithosphere at the lineae, in accordance with our results. It is worth to make clear, though, that the currently available geophysical evidence does not imply any particular geometry for the putative mantle downwelling beneath Lavinia Planitia. The nearly semi-circular pattern of the deformation 
field envisaged by the present work could be an important key to mantle geodynamics. The region containing the center of curvature, Alpha Regio, is mostly bounded by lowlands plains (except to the SE), which are bottom-loaded areas, maybe related to mantle downwellings, after the mapping of compensation mechanisms of Anderson and Smrekar (2006). Thus, the mantle downwelling inferred beneath Lavinia Planitia could actually be part of a roughly circular "super-downwelling" structure around Alpha Regio. Thus, our results suggest a certain relation between Alpha Regio evolution and that of the surrounding plains.

\section{Conclusions}

A detailed structural analysis of the deformation belts of Lavinia Planitia is presented in this work. The described structures show an irregular distribution across Lavinia Planitia, with wrinkle ridges and long grooves predominating in the smooth plains, and large ridges and grabens conforming the deformation belts. Complex arrangement of ridge belts with common sigmoid and stepped geometries can be found forming an intricate network covering Lavinia Planitia. These ridge belts embrace lozengeshaped areas that define topographic highs interpreted as push-up structures. Fracture belts similar to rift structures (e.g., Hippolyta Linea) are composed of numerous parallel grabens that often crosscut the ridge belts at high angles. The curved geometry and stepped alignment of many ridges, ridge belts and graben systems reveals the importance of transcurrent components of displacement at most deformation belts. Large transcurrent structures can be identified in some cases (e.g., southwestern branch of Molpadia Linea; Penardun Linea), in accordance with previous observations. The consequences of the activity of transpression and transtension tectonic regimes are commonly recognized at Lavinia Planitia. Along-strike azimuth changes of some deformation belts (e.g., Antiope Linea, Molpadia Linea) are accommodated by correlative changes in the proportion and geometry of extensional, contractional or transcurrent structures. In other cases, the same type of structure modifies its style to take up the consequences of azimuth changes in the deformation belt (e.g., ridge belts of area D).

The maximum horizontal shortening axes of the deformation field determined in this work take the shape of a semicircle centered at Alpha Regio. The main conclusion derived from this work is that the tectonic evolution of Lavinia Planitia cannot be understood in isolation, but that future work needs a careful analysis of its neighbor plateaus (e.g., Alpha Regio) and plains. The key to deciphering the dynamic evolution of Venus probably lies in the geological and geophysical analysis and modeling of the coeval evolution of huge regions with several thousands of kilometers across, comprising both lowlands and highlands. Those large regions are probably the true tectonic units of Venus. Ongoing projects of geological mapping, together with an intensive structural study of the distinct regions of Venus will aid to determine the number and limits of these units.

\section{Acknowledgments}

Assistance of Alfonso Muñoz Martín with the topographic information is gratefully acknowledged. J.R. was supported by a contract Juan de la Cierva for Earth Sciences, co-financed from the Ministerio de Ciencia e Innovación of Spain and the European Social Fund. I.R. was supported by a post-doc MEC-Fulbright contract. We are grateful to two anonymous reviewers who helped to improve the first version of the manuscript.

\section{References}

Anderson, F.S., Smrekar, S.E., 2006. Global mapping of crustal and lithospheric thickness on Venus. J. Geophys. Res. 111. doi:10.1029/2004JE002395.

Bilotti, F., Suppe, J., 1999. The global distribution of wrinkle ridges on Venus. Icarus $139,137-157$.

Bindschadler, D.L., Schubert, G., Head, J.W., 1992. Coldspots and hotspots: Global tectonics and mantle dynamics of Venus. J. Geophys. Res. 97, 13495-13532.

Bullock, M.A., Grinspoon, D.H., 1996. The stability of climate on Venus. J. Geophys. Res. 101, 7521-7529.

Bullock, M.A., Grinspoon, D.H., 2001. The recent evolution of climate on Venus. Icarus 150, 19-37

Conrad, C.P., Hager, B.H., 2001. Mantle convection with strong subduction zones. Geophys. J. Int. 144, 271-288.

Dauteuil, O., Huchon, P., Quemeneur, F., Souriot, T., 2001. Propagation of an oblique spreading centre: The western Gulf of Aden. Tectonophysics 332, 423-442.

Davison, I., Powell, D., 1991. Deformation along a mid-crustal continental strike-slip shear zone: The Pernambuco Lineament, NE Brazil. Mitt. Geol. Inst. ETH Zurich Newe Folge 239b, 14-15.

Dibblee, T.W., 1977. Strike-slip tectonics of the San Andreas fault and its role in Cenozoic basin evolvement. In: Nilsen. T.H. (Ed.) Late Mesozoic and Cenozoic Sedimentation and Tectonics in California. San Joaquin Geological Society, Bakersfield, CA pp. 26-38.

Ebert, H.D., Hasui, Y., 1998. Transpressional tectonics and strain partitioning during oblique collision between three plates in the Precambrian of southeast Brazil. In: Holdsworth, R.E., Strachan, R.A., Dewey, J.F. (Eds.), Continental Transpressional and Transtensional Tectonics, vol. 135. Geological Society of London, pp. 231-252 (Special Publications).

Fernández, C., Anguita, F., 2007 . Oblique rifting at Tempe Fossae, Mars. J. Geophys. Res. 112. doi: 10.1029/2007/E002889.

Ford, P.G., Pettengill, G.H., 1992. Venus topography and kilometer-scale slopes. I. Geophys. Res. 97, 13103-13114.

Frank, H.S.L., Head, J.W., 1990. Ridge be1ts on Venus: Morphology and origin. Earth Moon Planets (50/51), 421-470.

Ghent, R., Hansen, V.L., 1999. Structural and kinematic analysis of eastern Ovda Regio, Venus: Implications for crustal plateau formation. Icarus 139, 116 136.

Hansen, V.L. 2000. Geologic mapping of tectonic planets. Earth Planet. Sci. Lett. 176 $527-542$.

Hansen, V.L., 2007. Venus: A thin lithosphere analog for Earth. In: Van Kranendonk, M., Smithies, R.H., Bennet, V.C. (Eds.), Developments in Precambrian Geology, vol. 15. Elsevier, Amsterdam, pp. 987-1012.

Holdsworth, R.E., Strachan, R.A., Dewey, J.F. (Eds.), 1998. Continental Transpressional and Transtensional Tectonics. Geological Socieby, Specia Publication No. 135, London, UK

Ivanov, M.A., Head, J.W., 2001. Atlas of Venus: Lavinia Planitia quadrangle (V-55). USGS Geol. Invest. Series I-2684

Ivanov, M.A. Head, J.W. 2007. Geologic history of the Lavinia Planitia/Lada Terra region, Venus: Results of mapping in the $V-55, V-61$, and $V-56$ quadrangles. In: Lunar Planet. Sci. Conf. 38, 1032 (abstract).

Ivanov, M.A, Head, J.V., Morris, A., Russell, P., Stoddard, P., 2000. Deformation belts in Lavinia Planitia, Venus, Stratigraphy and relative ages. In: Lunar Planet. Sci. Conf. 31,1446 (abstract).

Koenig, E., Aydin, A., 1997. Nunerical modeling of possible strike-slip faulting in Lavinia Planitia, Venus. In: Lunar Planet. Sci. Conf. 28, 1808 (abstract).

Koenig, E., Aydin, A, 1998. Evidence for large-scale strike-slip faulting on Venus. Geology 26, 551-554.

Lawrence, K.P., Phillips, R.J., 2003. Gravity/topography admittance inversion on Venus using niching genetic algorithms. Geophys. Res. Lett. 30. doi:10.1029/ 2003GL017515.

Mackwell, S.J., Zimmerman, M.E., Kohlstedt, D.L., 1998. High-tenperature deformation of dry diabase with application to tectonics on Venus. I. Geophys. Res. 103, 975-984

Magee, K.P., Head, J.W., 1995. The role of rifting in the generation of melt: Implications for the origin and evolution of the Lada Terra-Lavinia Planitia region of Venus. J. Geophys. Res. 100, 1527-1552.

Mardia, K.V., 1972. Statistics of Directional Data. Academic Press, London, 357 pp.

Masursky, H., Eliason, E., Ford, P.G., McGill, G.E., Pettengill, G.H., Schaber, G.G., Schubert, G., 1980. Pioneer Venus radar results: Geology from images and altimetry. J. Geophys. Res. 85 (A13), 8232-8260.

McClay, K.R., Dooley, T., Whitehouse, P., Mills, M., 2002. 4-D evolution of rift systems: Insights fron scaled physical models. An. Assoc. Petrol. Geol. Bull. 86 935-959.

Moody, J.D., Hill, M.J., 1956. Wrench-fault tectonics. Geol. Soc. An. Bull. 67, $1207-$ 1246 .

Mueller, K, Golonbek, M., 2004. Compressional structures on Mars. Annu. Rev. Earth Planet. Sci. 32, 435-464.

Richard, P., Mocquet, B., Cobbold, P.R., 1991. Experintents on simultaneous faulting and folding above a basement wrench fault. Tectonophysics 188, 133-141.

Romeo, I., Capote, R., Anguita, F., 2005. Tectonic and kinematic study of a strikeslip zone along the southern margin of Central Ovda Regio, Venus: Geodynamical implications for crustal plateaux formation and evolution. Icarus $175,320-334$

Sandwell, D.T., Johnson, C.L., Bilotti, F., Suppe, J., 1997. Driving forces for limited tectonics on Venus. Icarus $129,232-244$. 
Schultz, R.A, 2000. Localization of bedding plane slip and backthrust faults above blind thrust faults: Key to winkle ridge structure. J. Geophys. Res. 105, 12035 12052 .

Squyres, S.W., Jankowski, D.G., Simons, M., Solomon, S.C., Hager, B.H., McGill, G.E., 1992. Plains tectonism on Venus: The deformation belts of Lavinia Planitia. J. Geophys. Res. 97, 13579-13599.

Sylvester, A.G., 1988. Strike-slip faults. Geol. Soc. Am. Bull. 100, 1666-1703.

Twiss, R.J., Moores, E.M., 1992. Structural Geology. W.H. Freeman and Company, New York, $532 \mathrm{pp}$.
Wilcox, R.E., Harding, T.P., Seely, D.R., 1973. Basic wrench tectonics. Am. Assoc. Petrol. Geol. Bull. 57, 74-96.

Woodcock, N.H., Schubert, C., 1994. Continental strike-slip tectonics. In: Hancock, P.L. (Ed.), Continental Deformation. Pergamon Press, Oxford, pp. 251-263.

Young, D.A., Hansen, V.L., 2005. Poludnista Dorsa, Venus: His tory and context of a deformation belt. J. Geophys. Res. 110. doi: $10.1029 / 2004$ JE002280.

Zuber, M.T., 1987. Constraints on the lithospheric structure of Venus from mechanical models and tectonic surface features. J. Geophys. Res. 92, E541E551. 